\title{
Fabrication of Multifunctional Hybrid Composites Using Fly Ash to Control Environmental Pollutants: A Review
}

\author{
Jun Cong Ge 1, Sam Ki Yoon² and Nag Jung Choi 1,* \\ 1 Division of Mechanical Design Engineering, Chonbuk National University, 567 Baekje-daero, \\ Jeonjusi 54896, Jeollabuk-do, Republic of Korea; freedefeng@naver.com \\ 1 Technical Education Center, GM Korea Company, 72 Saengmuol-ro, Gunsansi 573-882, Jeollabuk-do, \\ Republic of Korea; sky596072@hanmail.net \\ * Correspondence: njchoi@jbnu.ac.kr; Tel.: +82-63-270-4765
}

\begin{abstract}
Air pollutants such as volatile organic compounds (VOCs), nitrogen oxides (NOx), sulfur dioxide $\left(\mathrm{SO}_{2}\right)$, as well as water pollutants including heavy metal, are harmful to human and environment. Effective control and reduction of their pollution is therefore an important topic for today's scientists. Fly ash (FA) is a type of industrial waste that can cause multiple environmental problems if discharged into the air. On the other hand, because of its high porosity, large specific surface area, and other unique characteristics, the FA can also be used as a low-cost and high efficient adsorbent with some simple modifications. This paper reviews the effects of FA on treatment of the above air and water pollution based on our research experience over many years, including to the current status of global FA utilization, physicochemical properties, principle of adsorption, and the application direction of FA in the future. It focuses on the use of nanocomposite technology to fabricate functional FA fibrous membranes to adsorb VOCs from air, and treat heavy metal wastewater. This present review first describes the fabrication technology of FA nanocomposites and their mechanism of adsorption VOCs from air. Utilization of nanofiber technology to fabricate multi-functional FA emerging composite materials to mitigate air and water pollution has great potential in the future, especially use of pollutant material to control other pollutants.
\end{abstract}

Keywords: fly ash; nanocomposite; environmental pollution; volatile organic compounds; heavy metal

\section{Introduction}

Nanotechnology, nanocomposites, smart-technology, smart-living and others are buzzwords that represent the development of modern science and technology. Humans currently live in a time of rapid development, with daily life constantly becoming more high-tech and intelligent. However, in recent years, the threat posed by environmental pollution to human health and the environment has also increased. Such as air and water pollutions including nitrogen oxides (NOx) [1], volatile organic compounds (VOCs) [2], sulfur dioxide $\left(\mathrm{SO}_{2}\right)$ [3], heavy metal pollution [4]. Fly ash (FA), a type of industrial waste, is a coal combustion product composed of particulates [5]. With rapid industrial development, large demand for electricity has led to hundreds of millions of tons of FA (around $80 \%$ of which is fly ash) being discharged every year worldwide. The annual coal consumption of China in 2012 was about $50.2 \%$ of the global coal consumption [6]. Power generation using coal provides energy for daily life and industry, but it also produces atmospheric pollution, water pollution, all of which disrupt ecological cycles. FA pollutes the atmosphere and threatens human health if it is discharged directly from power plant chimneys into the atmosphere without treatment $[7,8]$. This is a significant contributor to China's recent air quality and haze problems $[9,10]$. 
However, with developing science and technology, FA from power plants is changing from industrial waste into an industrial raw material [11-13]. FA particles are porous and honeycombed, with large specific surface areas and high adsorption activities. FA particle sizes range from $0.5 \mu \mathrm{m}$ to $300 \mu \mathrm{m}$, and their bead walls have porosities of $50 \%-80 \%$ with high water absorption [14]. In addition, FA contains valuable oxide components, such as $\mathrm{SiO}_{2}, \mathrm{Al}_{2} \mathrm{O}_{3}, \mathrm{CaO}, \mathrm{MgO}, \mathrm{Na}_{2} \mathrm{O}, \mathrm{TiO}_{2}$, and essential elements, including $\mathrm{P}, \mathrm{K}, \mathrm{Mg}, \mathrm{Zn}, \mathrm{Fe}, \mathrm{Mn}$, and others [5,7]. Therefore, FA has attracted the attention of many researchers. FA is a pozzolanic mixture that is formed by high temperature combustion of pulverized coal. Its chemical composition is similar to clay, with a good lime binding capacity. Thus, it is primarily used for production of cement [15], clay bricks [16], hollow blocks [17], aerated concrete [18], and other building materials [19-21]. It can be also be used as an agricultural fertilizer and soil conditioner due to its low bulk density, high water retention capacity, favorable $\mathrm{pH}$, and other properties [6,22,23]. Ram et al. [24] studied the effects of FA on rice crop production from 1996 to 2000 and found that FA improved texture, fertility, and crop productivity of mine spoil. Figure 1 shows the value of conversion of industrial waste FA into various useful products.

FA can also be used as a low-cost adsorbent because of its excellent specific surface area, porosity, particle size [25], water retention capacity [14], and other natural characteristics [26]. Ram et al. [27] showed that FA could leach trace metals with efficiencies that vary with FA concentration, degree of association with ash particles, leaching duration, and $\mathrm{pH}$ of the leachate. Bhattacharyya et al. [28] found that FA could be used as an adsorbent in a cascade with a plasma reactor to NOx emission from biodiesel engines. Hower et al. [29] showed that FA carbon captures $\mathrm{Hg}$ efficiently. Other researchers have found that, after simple modification, FA is a good adsorbent of $\mathrm{SO}_{2}$ [30] and VOCs [31]. Furthermore, one-step fabrication of FA into a fibrous membrane by electrospun technology to adsorb VOCs from air has been successfully reported by our research group [32,33]. On the other hand, FA can also be combined with $\mathrm{TiO}_{2}$ [34] or $\mathrm{AgNO}_{3}$ [35] to produce a multifunctional fibrous membrane under electrospinning for purifying water, such as adsorption of heavy metals $(\mathrm{Hg}, \mathrm{Pb})$, removal of dyes (methylene blue), antibacterial activity, carcinogenic arsenic (As) and toxic organic dyes. Fabrication of multifunctional hybrid composites using pollutant material (fly ash) to control other pollutants that plays an important role in reducing and controlling environmental pollution. In addition, the perfect combination of nanotechnology and FA can reduce environmental pollution while producing low-cost and high-performance nanocomposites.

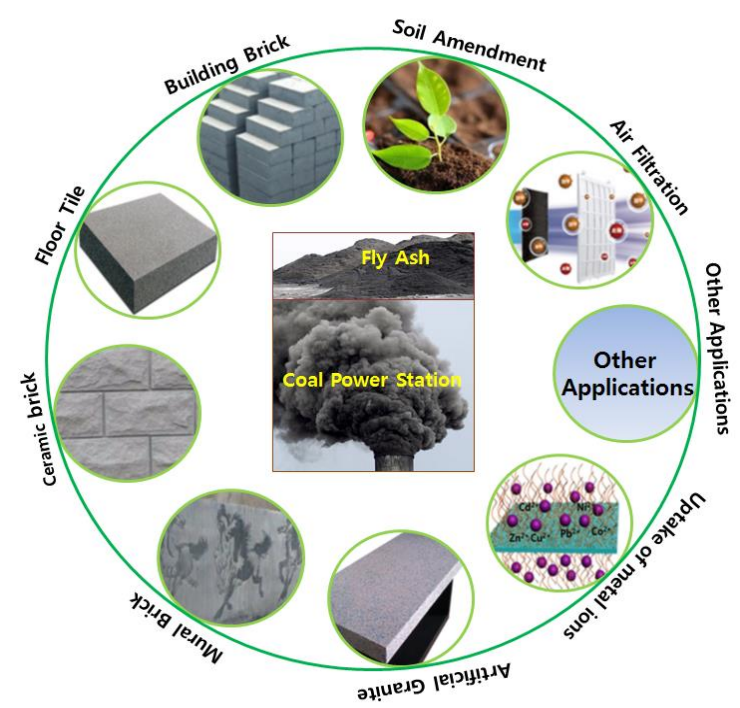

Figure 1. Various application values of the fly ash.

\section{Global overview of fly ash}

\subsection{China}


China is a populous country with high electricity consumption per capita. Coal is one of the main energy sources in China, accounting for 70\% of the total energy consumption from 1978 to 2009 [36]. China is the largest coal mining and consuming country in the world, and it has surpassed Japan to become the world's largest coal-importing country since 2008 [36]. China consumed more than 3 billion tons of coals in 2010 [37], and most cities in northern China use coal-fired heating in the winter. Figure 2 shows the coal consumption of China compared with other countries and its relationship with GDP. China clearly is dependent on energy from coal. However, burning coal produces FA in the air that causes environmental problems such as acid rain, fog and haze, and heavy metal pollution [38-40]. Solving the problem of FA pollutant from burning coal would be a great contribution to environmental and human health.

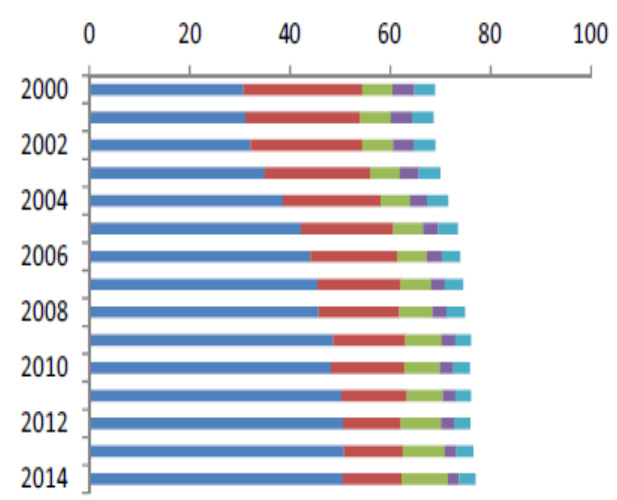

(a)

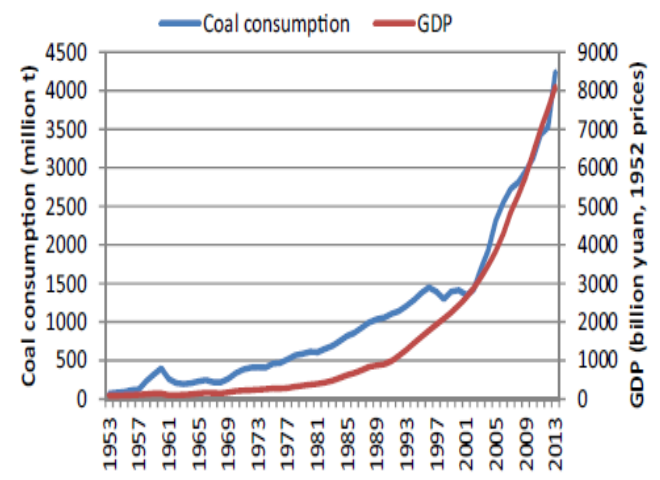

(b)

Figure 2. Comparison of coal consumption in China with other important coal consuming countries (a); relationship between coal consumption and GDP in China (b) [36].

Figure 3 shows the production and utilization rate of FA from 2001 to 2015 and the degree of utilization of FA in different cities of China in 2010. The annual output of FA is huge in China. At the end of 2015, about 580 million tons of FA were produced, accounting for about $77 \%$ of the global FA production [41]. FA utilization in China increased after 2004 and reached about 70\% in 2015 (Figure $3 a)$, which is closely related to the rapid development of China's economy and technology. However, different statistical offices have different estimates of the utilization rate of fly ash in China. For example, Greenpeace [41] estimated the utilization rate to be only $30 \%$. Regardless of the value, the utilization rate of FA in China is very high. According to statistics, the global average utilization rate of FA is about $25 \%$ [42]. Other researchers [43-45] reported that the utilization rate of FA is about $67 \%$. The utilization rate of FA in different cities in China is shown in Figure $3 b$. The utilization rate of fly ash in eastern China is clearly higher than in western China, due to the large market for FA in the east [37]. The specific utilization of FA is shown in Table 1. Although there are many ways to utilize FA in China, few technologically advanced products use FA. If processes involving FA are not strictly controlled, they can cause secondary pollution [46].

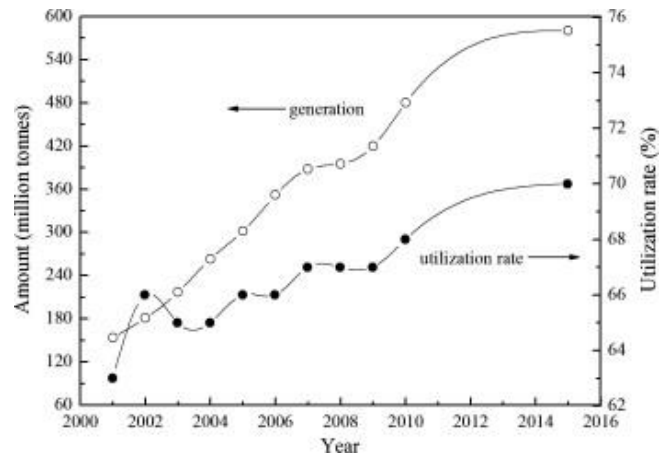

(a)

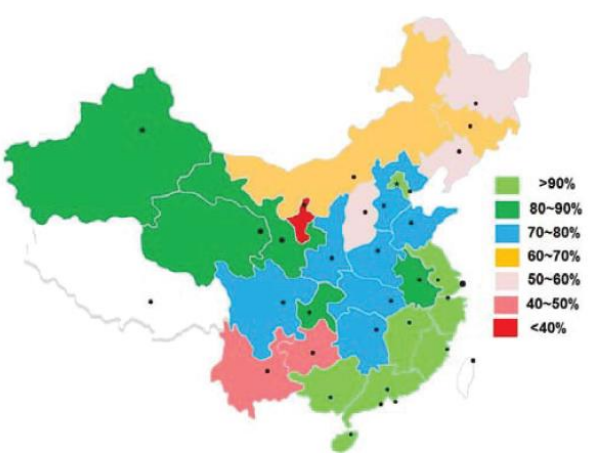

(b) 
Figure 3. Production and utilization of fly ash from 2001 to 2015 (a) [41]; comprehensive utilization rate of fly ash in Chinese cities in 2010 (b) [37].

Table 1. Specific utilization of fly ash in China.

\begin{tabular}{lc}
\hline \multicolumn{1}{c}{ Item } & $\begin{array}{c}\text { Specific utilization } \\
\text { Building materials } \\
\text { Road construction }\end{array}$ \\
$\begin{array}{l}\text { Cement, fly ash bricks, fly ash ceramics, fly ash blocks, } \\
\text { concrete, mortar }\end{array}$ \\
Backfill \\
$\begin{array}{l}\text { Embankments, pavement bases and pavement } \\
\text { Agriculture } \\
\text { Recycling useful } \\
\text { materials }\end{array}$ \\
$\begin{array}{l}\text { areas and wastelands, filling mines, filling coal mining } \\
\text { subsidence areas, building materials for pits, tidal marshes } \\
\text { Soil improvement, fertilizer production, land reclamation }\end{array}$ \\
\hline
\end{tabular}

\subsection{India}

About $65 \%$ of the Indian population uses coal as the main source of electricity [47]. Power generation in India has increased from 1360 MW in 1947 to about $200 \mathrm{GW}$ in 2012 and is expected to increase to $290 \mathrm{GW}$ in 2047 [48]. Annual production of FA in India is therefore also increasing rapidly. From 2015 to 2016, India consumed about 640 million tons of coal (about 25\% of the total coal consumption) for power generation [48]. In addition, the quality of coal in India is lower than in most advanced countries, with about $40 \%$ ash. This means that plants produce $0.74 \mathrm{Kg} / \mathrm{KWh}$ of power generation, which is $41 \%$ higher than the global average [48]. That is, the poorer is the quality of coal, the more pollutants are produced, such as PM, NOx, and SOx. India production of FA from 1996 to 2011 is shown in Figure 4a. Production of FA during 2010 and 2011 increased to about 130 million tons, which was about $85.7 \%$ higher than during 1996 to 1997 . The FA utilization rate also increased from $9.63 \%$ in 1996 to 1997 to $54.53 \%$ in 2010 to 2011 (Figure 4a), an increase of $466 \%$ over a 15 year period. This shows that people are aware of the value of FA utilization with technological advances and increased incomes. Figure $4 \mathrm{~b}$ shows uses of FA in India [49]: $42 \%$ for cement, $13 \%$ for bricks and tiles, $11 \%$ for land reclamation, $11 \%$ for mine filling, $8 \%$ for ash dyke raising, $5 \%$ for roads and flyover, $2 \%$ for agriculture, $1 \%$ for concrete, and $7 \%$ for other uses [49]. In addition, with the promulgation of the new policy in India, the Ministry of Environment, Forests, and Climate Change (MoEFCC) has revised standards for FA usage and disposal by granting permission to use it for agriculture. The ministry has also made it mandatory for power plants to provide FA free of charge to users within a 300-kilometre-radius, and cement industries are required to be setup within 300 kilometers of a coal power plant to increase utilization of FA and reduce costs [48]. Parab et al. [50] and other researchers [51-55] found that FA of India can improve soil structure and be used to reclaim dumps and degraded soils by making soil more fertile and increasing the yield of agricultural products. Given the advantages of FA and the policies in place in India, it is expected that the utilization rate of FA in India will continue to increase in the near future. 


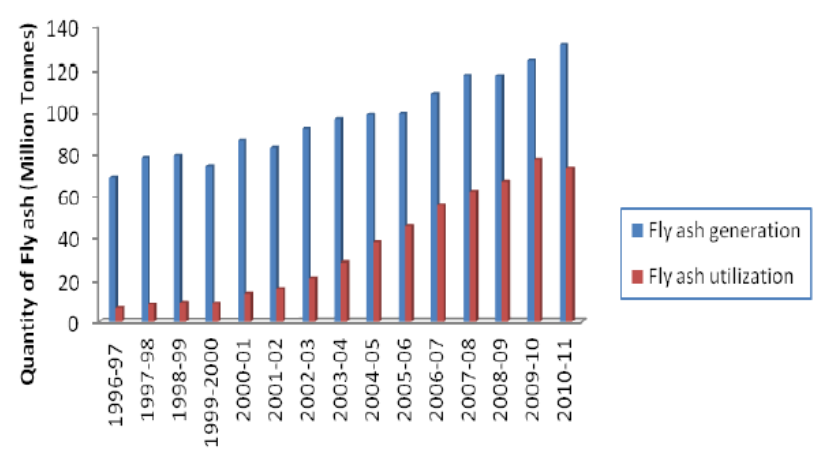

(a)

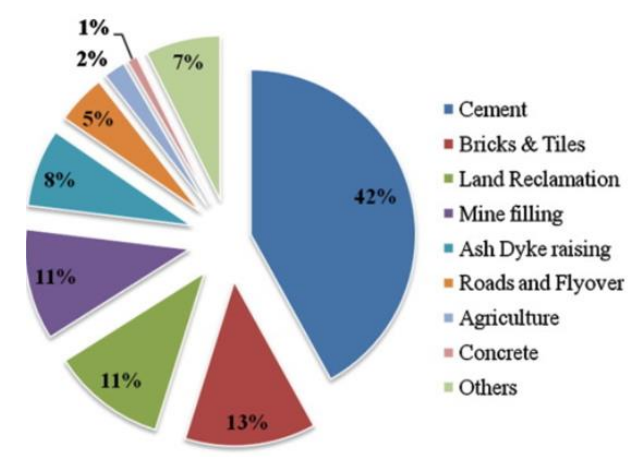

(b)

Figure 4. Production and utilization of fly ash (a) and uses of fly ash in India (b) [49].

\subsection{USA}

The United States has multiple energy sources and high energy efficiency due to their advanced technology and equipment. Americans use many types of energy, including petroleum, natural gas, coal, renewable energy, and nuclear electric power. The energy consumption of the United States in 2016 is displayed in Figure 5a. The total United States primary energy consumption was about 97.4 quadrillion Btu, only $15 \%$ of which was coal. Natural gas and renewable energy accounted for $39 \%$ of total energy. Although renewable energy only accounted for $10 \%$, it includes many sources such as biomass waste, biofuel, and hydroelectric. It can be inferred that the United States has a strong sense of environmental protection, which makes it particularly favor use of clean energy based on advanced technology. Because of these factors, coal-fired power generation in the United States is not substantial. The energy consumption for power stations in 2013 is shown in Figure 5b. It can be clearly seen that the United States relies mainly on natural gas to generate electricity, which accounts for about $50.8 \%$ of energy production. Coal accounts for only $21.9 \%$ of all power generation. The growth rate of FA in the United States is very slow, as shown in Figure 6. FA production grew from 53.4 million short tons in 2013 to 54.6 million short tons in 2033, an increase of just under 3\% [56]. Basu et al. [23] reported that utilization of FA in the United States is as high as 65\%. FA is mainly used in mine fill, cement, wallboard, snow and ice control, agriculture, and cosmetics in the United States. The use of FA in cement kilns in the United States has grown from about 1 million tons in 2001 to more than 4 million tons in 2006. FA is also used in a number of consumer products, including bowling balls and carpeting. In muddy feedlots, FA is used to absorb excess water. Coal ash is also used along with salt to help clear snowy and icy roads and to provide tire traction $[57,58]$. In addition, housing projects and rising demand in the ready-mixed concrete market are expected to be major drivers for future FA utilization in the United States [56].

U.S. energy consumption by energy source, 2016

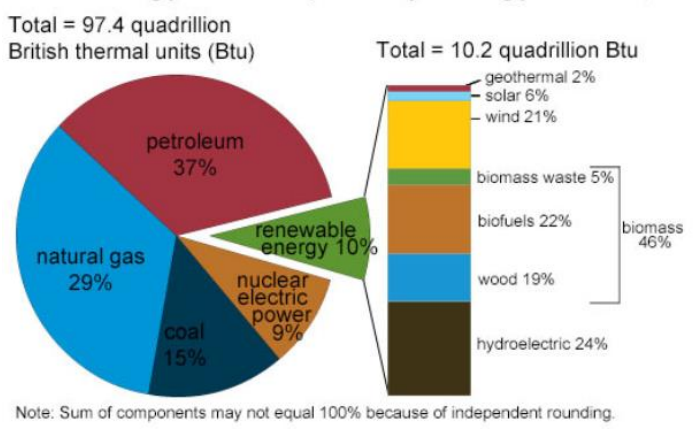

(a) 


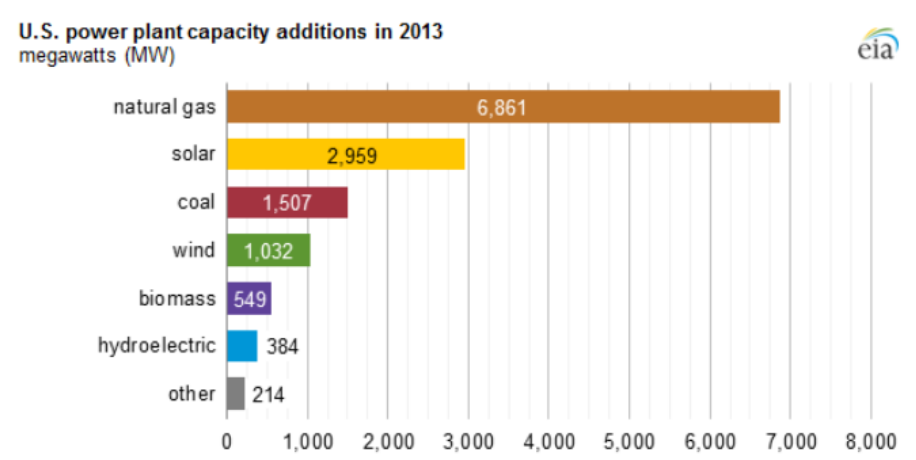

(b)

Figure 5. Energy consumption in the United States in 2016 (a) [57] and energy consumption of power stations in the United States in 2013 (b) [58].

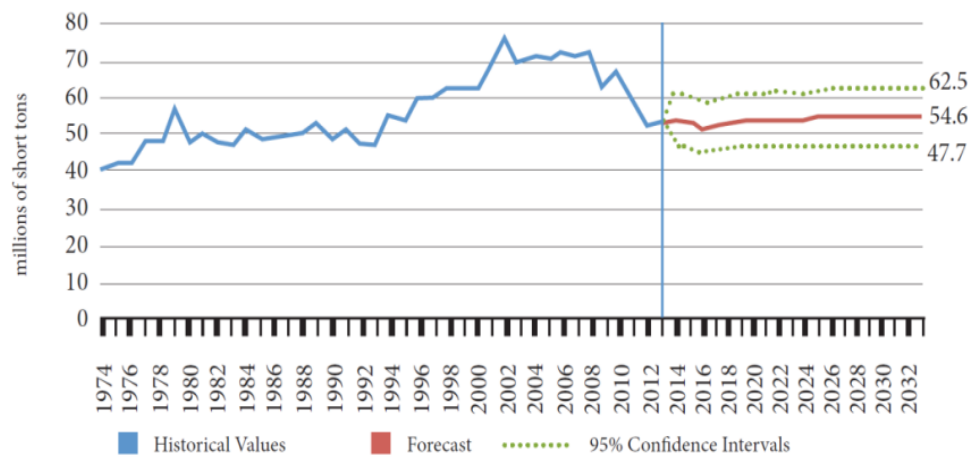

Figure 6. Coal consumption in the United States from 1974 to 2033 [56].

\subsection{Other countries}

Other countries produce a small amount of FA from coal-fired power. For example, Germany produces 40 million tons per year, the UK produces 15 million tons, and Australia produces 10 million tons. The annual production of FA has not reached 10 million tons per year in Canada, France, Denmark, Italy, or the Netherlands. These countries produce very little FA every year compared to China and India, but their FA utilization is high. The average utilization rate of Germany, the UK, Australia, Canada, and France is $76 \%$. The average of Denmark, Italy, and the Netherlands is up to $100 \%$. FA is used in the same ways in these countries as in China, India, and USA $[23,50,59]$.

\section{Physical and chemical properties of fly ash}

The physical and chemical properties of FA play an important role in its study, including its morphology, its chemical properties and its mineralogical properties. FA properties may vary depending on combustion conditions and collector setup. The average size of FA fine particles is less than 20 microns, with a bulk density of $0.54-0.86 \mathrm{~g} / \mathrm{cm}^{3}$, a surface area of $300-500 \mathrm{~m}^{2} / \mathrm{kg}$, and a $\mathrm{pH}$ value of 1.2-12.5. FA can be classified into three main groups of acidic ash, mildly alkaline ash ( $\mathrm{pH} 8$ 9), and strongly alkaline ash (pH 11-13) [6].

\subsection{Morphological characteristics}

Figure 7 and Figure 8 show scanning electron microscopy (SEM) images of FA. Figures 7a and 7b show the morphological characteristics of non-carbonated FA, including different sized spherical particles, cenospheres, and plerospheres. Most of the small particles are well-rounded and solid spheres. Some large particles are vesicular cenospheres due to the presence of gas bubbles or vapor [60]. Figures 7c and 7d show morphologies after FA carbonization, which has the "cubic-like" structures of calcite (Figure 7c) and "needle-like" structures of aragonite (Figure 7d). In addition, FA particles are reported to be globular and irregular with high porosity [61], glassy cenospheres [62- 
64], spherical-shaped and flake-like particles [65,66], spherical particles of varying sizes and particles of unburned coal $[62,67,68]$, and predominantly spherical in shape and consisting of solid spheres, cenospheres, irregular-shaped debris and porous unburnt carbon [6]. The morphological characteristics of FA depend on particle size, but cenospheres are an exception. FA precipitators are sized between 20-53 $\mu \mathrm{m}$ and 75-106 $\mu \mathrm{m}$, while cenospheres are 20-45 $\mu \mathrm{m}$ and 106-150 $\mu \mathrm{m}$ [62]. FA particles smaller than $20 \mu \mathrm{m}$ consist of mostly smooth spherical particles, while a large number of irregularly shaped grains are between 75 and $106 \mu \mathrm{m}$, and a small number of irregularly shaped vesicular grains are more than $150 \mu \mathrm{m}$ (see Figure 8 for details) [69].
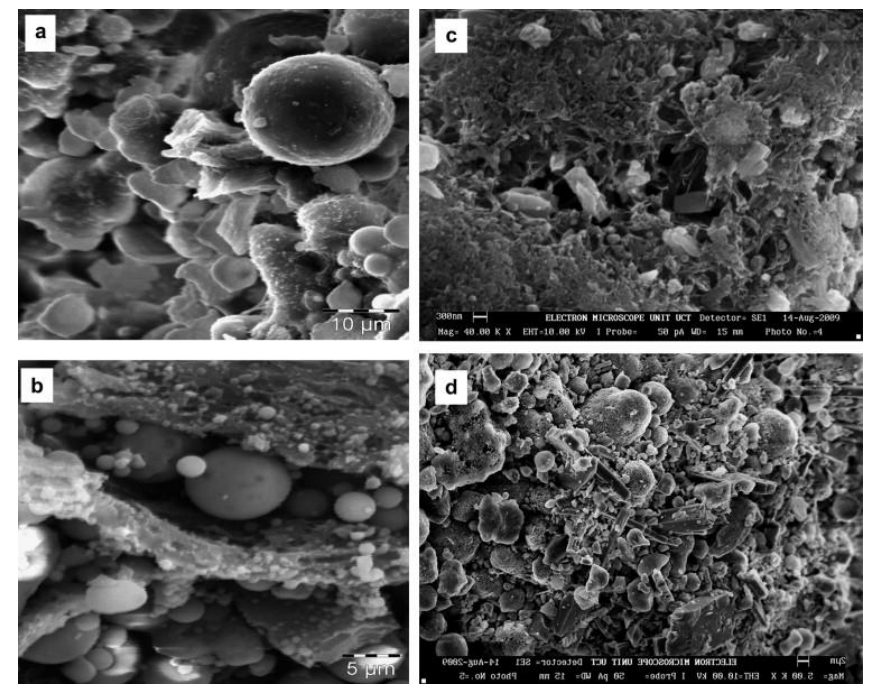

Figure 7. SEM images of non-carbonated ( $a$ and $b$ ) and carbonated (c and d) fly ash [60].

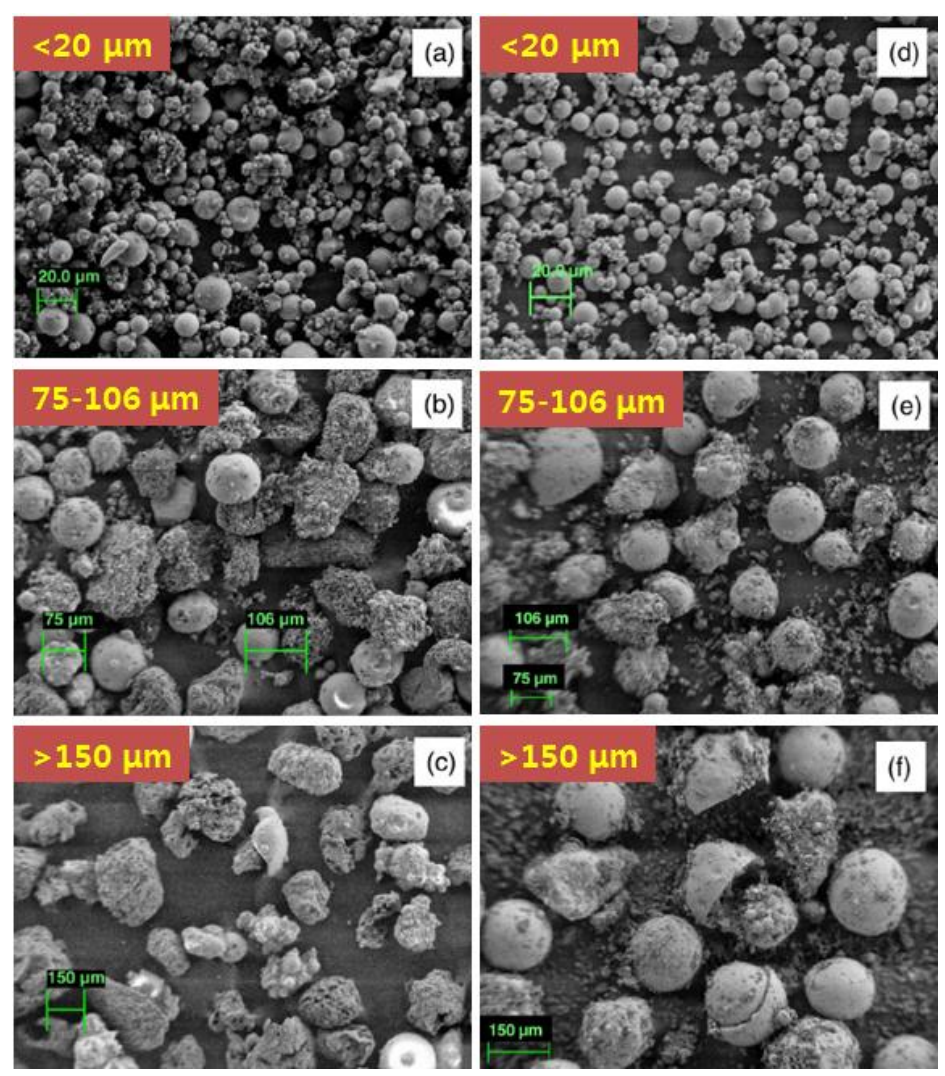

Figure 8. SEM images of fly ash particles; a-c and d-f are before and after removal of unburned carbon by combustion, respectively [69]. 


\subsection{Chemical and mineralogical composition}

The chemical and mineralogical composition of FA plays an important role in the analysis of the application and disposal of FA, including its use as a cement replacement material. The chemical composition of FA can be determined by X-ray fluorescence (XRF) and spectrometry techniques. Researchers [70-76] have reported that FA is composed of $\mathrm{SiO}_{2}, \mathrm{Al}_{2} \mathrm{O}_{3}, \mathrm{Fe}_{2} \mathrm{O}_{3}, \mathrm{CaO}, \mathrm{MgO}, \mathrm{Na}_{2} \mathrm{O}, \mathrm{K} 2 \mathrm{O}$, $\mathrm{TiO}_{2}, \mathrm{P}_{2} \mathrm{O}_{5}$, and small amounts of $\mathrm{MnO}, \mathrm{BaO}$, and $\mathrm{SO}_{3}$. The detailed chemical composition of fly ash is given in Table 2. Some heavy metals are also found in $\mathrm{FA}$, such as $\mathrm{Cd}, \mathrm{Co}, \mathrm{Cr}, \mathrm{Cu}, \mathrm{Mn}, \mathrm{Ni}, \mathrm{Pb}$, and Zn [76,77], as shown in Table 3. The chemical composition of FA may differ based on geographical origin and combustion conditions. However, the chemical composition is generally dominated by $\mathrm{SiO}_{2}$, followed by $\mathrm{Al}_{2} \mathrm{O}_{3}, \mathrm{Fe}_{2} \mathrm{O}_{3}, \mathrm{CaO}, \mathrm{MgO}, \mathrm{Na}_{2} \mathrm{O}, \mathrm{K}_{2} \mathrm{O}, \mathrm{TiO}_{2}$, and $\mathrm{P}_{2} \mathrm{O}_{5}$. FA can also be divided into high calcium ash $(\geq 10 \% \mathrm{CaO})$ and low calcium ash $(<10 \% \mathrm{CaO})$, according to the content of $\mathrm{CaO}$. High calcium ash can remove acidic gases and fix hazardous heavy metals, such as $\mathrm{Cd}$ and $\mathrm{Cu}$ [76]. $\mathrm{CaO}$ is present in FA as free lime and embedded in glassy spheres. Usually, the $\mathrm{CaO}$ content increases with decreasing particle size [60]. Loss on ignition (LOI) has long served as a standard method to measure unburned carbon in FA [77-79]. All types of FA have a certain LOI value indicating their unburnt carbon content (Table 2). Unburnt carbon in FA powder has properties similar to activated carbon, such as good adsorption capacity.

Some minerals in FA can be measured by X-ray diffraction (XRD) and infrared spectroscopy techniques. Nyambura et al. [60] analyzed the XRD spectra of non-carbonated and carbonated FA, as shown in Figure 9. Minerals in non-carbonated FA were found to mainly consist of amorphous, $\mathrm{CaO}$, hematite, mullite, and quartz (see Fig. 9a). The minerals in carbonated FA are mainly composed of amorphous $\mathrm{CaCO}_{3}$, magnetite, mullite, plagioclase, quartz, bassanite, and anhydrite (see Fig. 9a). The major crystalline phases are mullite and quartz for most ash [80-83]. The $\mathrm{CaO}$ in non-carbonated FA is converted into calcite (main component: $\mathrm{CaCO}_{3}$ ) when it is carbonized. These results have been described in SEM spectrum analysis, and the "cubic-like" structures in Figure 9c are calcites [60]. Many other researchers have also confirmed these results [84,85]. Among the many oxides in FA, recovery of alumina has attracted interest in recent decades. Therefore, as science and technology progresses, the recovery and utilization of industrial waste to benefit humans and the environment will help reduce environmental impacts.

Table 2. Primary chemical compositions of different types of fly ash [86].

\begin{tabular}{lccccccccccc}
\hline $\begin{array}{c}\text { Type } \\
\text { of fly } \\
\text { ash }\end{array}$ & $\begin{array}{c}\text { Unit } \\
\text { (wt.) }\end{array}$ & $\mathrm{SiO}_{2}$ & $\mathrm{Al}_{2} \mathrm{O}_{3}$ & $\mathrm{Fe}_{2} \mathrm{O}_{3}$ & $\mathbf{C a O}$ & $\mathbf{M g O}$ & $\mathrm{Na}_{2} \mathrm{O}$ & $\mathrm{K}_{2} \mathrm{O}$ & $\mathrm{TiO}_{2}$ & $\mathbf{P}_{2} \mathrm{O}_{5}$ & $\mathbf{L O I}^{\mathbf{b}}$ \\
\hline $\mathrm{B}$ & $\%$ & 47.1 & 23.0 & 20.4 & 1.21 & 1.17 & 0.54 & 3.16 & 0.85 & 0.16 & 2.88 \\
$\mathrm{~B}$ & $\%$ & 44.1 & 21.4 & 26.8 & 1.95 & 0.99 & 0.56 & 2.32 & 0.80 & 0.25 & 0.70 \\
$\mathrm{~B}$ & $\%$ & 35.5 & 12.5 & 44.7 & 1.89 & 0.63 & 0.10 & 1.75 & 0.56 & 0.59 & 0.75 \\
$\mathrm{~B}$ & $\%$ & 38.3 & 12.8 & 39.7 & 4.49 & 0.43 & 0.14 & 1.54 & 0.59 & 1.54 & 0.88 \\
$\mathrm{~B}$ & $\%$ & 45.1 & 22.2 & 15.7 & 3.77 & 0.91 & 0.58 & 1.52 & 0.98 & 0.32 & 9.72 \\
$\mathrm{~B}$ & $\%$ & 48.0 & 21.5 & 10.6 & 6.72 & 0.96 & 0.56 & 0.86 & 0.91 & 0.26 & 6.89 \\
$\mathrm{SB}$ & $\%$ & 55.7 & 20.4 & 4.61 & 10.7 & 1.53 & 4.65 & 1.00 & 0.43 & 0.41 & 0.44 \\
$\mathrm{SB}$ & $\%$ & 55.6 & 23.1 & 3.48 & 12.3 & 1.21 & 1.67 & 0.20 & 0.64 & 0.13 & 0.29 \\
$\mathrm{SB}$ & $\%$ & 62.1 & 21.4 & 2.99 & 11.0 & 1.76 & 0.30 & 0.72 & 0.65 & 0.10 & 0.70 \\
$\mathrm{~L}$ & $\%$ & 46.3 & 22.1 & 3.10 & 13.3 & 3.11 & 7.30 & 0.78 & 0.78 & 0.44 & 0.65 \\
$\mathrm{~L}$ & $\%$ & 44.5 & 21.1 & 3.38 & 12.9 & 3.10 & 6.25 & 0.80 & 0.94 & 0.66 & 0.82 \\
\hline
\end{tabular}

${ }^{a}$ B: Bituminous; SB: Subbituminous; L: Lignite.

${ }^{\mathrm{b}}$ LOI: Loss on ignition. 
Table 3. Leaching toxicities of fly ash from some cities of China [76].

\begin{tabular}{lcccccccc}
\hline $\begin{array}{l}\text { Heavy } \\
\text { metals }\end{array}$ & Unit & Yuqiao & Yanqian & Nanshan & Dadi & Jiangqiao & Laohukeng & I.S. $^{1}$ \\
\hline $\mathrm{Cd}$ & $\mathrm{mg} / \mathrm{L}$ & 0 & 31.21 & 0.01 & 0 & 0 & - & 0.3 \\
$\mathrm{Cr}$ & $\mathrm{mg} / \mathrm{L}$ & 0.121 & - & - & 1.701 & 0.692 & 0.067 & 10 \\
$\mathrm{Cu}$ & $\mathrm{mg} / \mathrm{L}$ & 0.141 & 0.42 & 0.10 & 1.190 & 0.202 & 0.336 & 50 \\
$\mathrm{~Pb}$ & $\mathrm{mg} / \mathrm{L}$ & 67.03 & 11.80 & 1.13 & 0 & 27.71 & 50.85 & 3 \\
$\mathrm{Zn}$ & $\mathrm{mg} / \mathrm{L}$ & 0.952 & 164.90 & 0.23 & 0.049 & 2.687 & 5.250 & 50 \\
\hline \multicolumn{7}{c}{ Identification standard for hazardous wastes (GB5086.1-1997). }
\end{tabular}

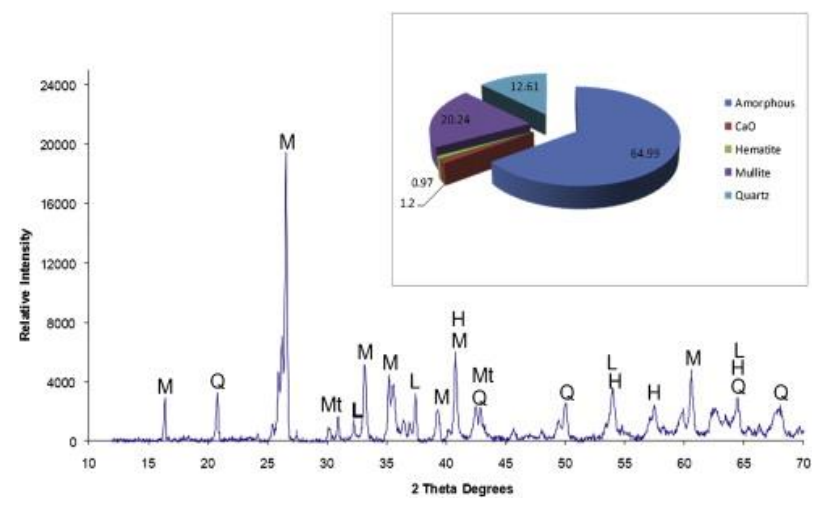

(a)

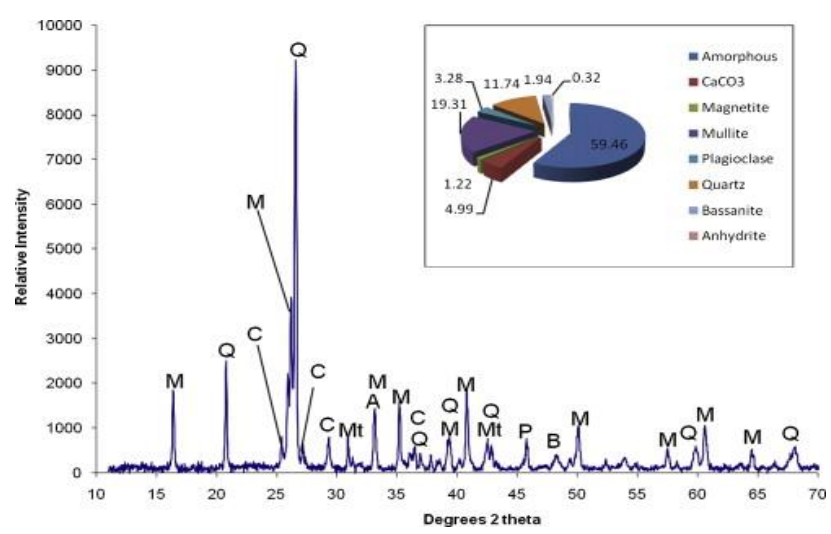

(b)

Figure 9. XRD patterns of non-carbonated (a) and carbonated (b) FA; M (mullite), Q (quartz), C (calcite), A (anhydrite), P (plagioclase), B (bassanite), Mt (magnetite), L (lime), and H (hematite) [60].

\section{Application of fly ash for treatment of pollutants}

\subsection{Removing air pollutants}

As a cheap adsorbent, FA can effectively reduce environmental pollution through simple processing because it has a high porosity and specific surface area, in addition to other useful characteristics. Pollutants that can be adsorbed by FA include volatile organic compounds (VOCs), nitrogen oxides (NOx) and sulfur dioxide $\left(\mathrm{SO}_{2}\right)$.

\subsubsection{Volatile organic compounds}

Volatile organic compounds (VOCs) are one of air pollutants mainly produced by fossil fuel combustion [87,88], painting [89], refining [90], building [91], and other industries [92,93]. In recent 
decades, rapid development of industry has led to a dramatic increase in anthropogenic VOCs. There are more than about 300 chemical structures of VOCs, which can be classified as alkanes, aromatics, esters, and aldehydes, among others [94,95]. Many VOCs are harmful to humans in even small amounts, such as benzenes and formaldehyde, which are suspected carcinogens [96]. Xylene and aliphatic hydrocarbons are mainly produced by the paint industry and are harmful to the environment and humans [97,98]. Polycyclicaromatic hydrocarbons (PAHs) are a group of VOCs containing several benzene rings, have been identified as carcinogenic VOCs [99]. In sunlight, photochemical reactions of VOCs and NOx will generate ozone, peroxide, nitro-aldehydes, and other photochemical smog compounds that cause secondary pollution and affect people's eyes and respiratory systems, endangering human health [100-103]. Table 4 shows some VOCs harmful to human health [104]. Thus, the reduction and control of VOCs from air are important research topics for air purification.

Table 4. Sources and health effects of major volatile organic compounds [104].

\begin{tabular}{|c|c|c|c|c|}
\hline $\begin{array}{l}\text { Volatile organic } \\
\text { compounds }\end{array}$ & $\begin{array}{c}\text { Dangerous } \\
\text { concentration }\end{array}$ & Unit & Sources & Health effects \\
\hline Benzene & 500 & ppm & \multirow{3}{*}{$\begin{array}{c}\text { Petroleum products; } \\
\text { Incomplete combustion of } \\
\text { liquid fuels; Adhesives; } \\
\text { Lacquers }\end{array}$} & \multirow{3}{*}{$\begin{array}{c}\text { Carcinogen; } \\
\text { Damage the ozone layer; } \\
\text { Produce photochemical } \\
\text { smog \& pose mutagenic } \\
\text { hazards }\end{array}$} \\
\hline Toluene & 500 & ppm & & \\
\hline Ethylbenzene & 800 & ppm & & \\
\hline Carbon tetrachloride & 200 & ppm & \multirow{7}{*}{$\begin{array}{c}\text { Chemical extractants; } \\
\text { Paints; Adhesives; } \\
\text { Polymer syntheses; } \\
\text { Water purification systems }\end{array}$} & \multirow{7}{*}{$\begin{array}{c}\text { Strong bioaccumulation } \\
\text { potential; Acute toxicity; } \\
\text { Destruction of the ozone; } \\
\text { Cause greenhouse gas } \\
\text { effects }\end{array}$} \\
\hline Chlorobenzene & 1000 & ppm & & \\
\hline 1,1,2-Trichloroethane & 100 & ppm & & \\
\hline $1,1,2,2-$ & 100 & ppm & & \\
\hline Trichloroethylene & 1000 & ppm & & \\
\hline Tetrachloroethylene & 150 & ppm & & \\
\hline Dichloromethane & 150 & ppm & & \\
\hline Acetone & 2500 & ppm & \multirow{2}{*}{$\begin{array}{c}\text { Varnishes; Window } \\
\text { cleaners; } \\
\text { Paint thinners; Adhesives }\end{array}$} & \multirow{2}{*}{$\begin{array}{c}\text { Irritation of eyes, nose, \& } \\
\text { throat; Central nervous } \\
\text { system depression; } \\
\text { Headache and nausea }\end{array}$} \\
\hline Ethyl butyl ketone & 1000 & ppm & & \\
\hline Formaldehyde & 20 & ppm & $\begin{array}{l}\text { Decorative \& construction; } \\
\text { Materials; Cosmetics \& } \\
\text { plastic adhesives; Fabrics } \\
\text { \& bio-waste decomposition; }\end{array}$ & $\begin{array}{c}\text { Irritation of the throat, } \\
\text { eyes, }\end{array}$ \\
\hline Acetaldehyde & 2000 & ppm & $\begin{array}{l}\text { Biomass burning; } \\
\text { Degradation of VOCs in } \\
\text { multiple steps oxidations }\end{array}$ & $\begin{array}{l}\text { \& skin; Nasal tumors; } \\
\text { Predecessor of ozone }\end{array}$ \\
\hline Methanol & 6000 & ppm & \multirow{3}{*}{$\begin{array}{c}\text { Antiseptics; Preservative; } \\
\text { Cosmetics \& personal care } \\
\text { products }\end{array}$} & \multirow{3}{*}{$\begin{array}{l}\text { Throat irritation \& } \\
\text { shortness of breath; } \\
\text { Eye irritation; Central } \\
\text { nervous system } \\
\text { depression }\end{array}$} \\
\hline Ethyl alcohol & 3300 & ppm & & \\
\hline Isopropyl alcohol & 2000 & ppm & & \\
\hline
\end{tabular}

Seo et al. [105] evaluated adsorption capacity of 7 building materials (activated carbon, gypsum board mixed with a given quantity of activated carbon, board made out of activated carbon, 
humidity-controlling porous ceramic material, humidity-controlling silicate calcium, ceramic tile and ordinary gypsum board) for adsorption of 4 kinds of VOCs in a small test chamber. They showed that activated carbon has the highest VOCs adsorption capacity compared with other building materials. Chmielewski et al. [106] studied the reduction of VOCs from coal combustion using electron beam treatment and found that the concentration of polycyclic aromatic hydrocarbons (VOCs) was greatly reduced from $40 \%$ to $98 \%$. Other researchers have also found that other materials effectively reduce VOCs, including cashew nut shell liquid [107,108], Sol-Gel [109], dairy lagoon [110], $\mathrm{CuO}-\mathrm{CeO}_{2}$ mixed oxides [111], $\mathrm{Mn}-\mathrm{Cu}$ mixed oxide [112], manganese oxides [113], and other metal oxide catalysts $[114,115]$. Among them, activated carbon is one of the most common adsorbents because of its low-cost, high availability, excellent specific surface area, pore size, porosity, chemical functional group, and other properties [116-118]. Nevertheless, activated carbon adsorption of macromolecules and hydrophilic VOCs is not good because it has a multi-microporous structure and is a nonpolar adsorbent [104]. On the other hand, activated carbon fibers adsorb VOCs better than activated carbon because of their short and straight thin-fiber shaped micropores that increase intraparticle adsorption kinetics compared to activated carbon [119,120]. In addition, activated carbon fibers also play an important role during adsorption or desorption, they have large adsorption capacity and high mass transfer rates [121,122].

Similar to adsorption on activated carbon fibers, FA can be used to fabricate a functional adsorption fibrous membrane through simple electrospinning. Electrospinning is an efficient method for fabricating fibers from nanometer to micrometer, with advantages of high efficiency, low cost, easy operation [123]. Figure 10 shows a schematic of an electrospun fibrous membrane and a VOCs adsorption experiment. Kim et al. [33] successfully synthesized polyurethane fibers containing different amounts of FA and analyzed their adsorption of chloroform, benzene, toluene, xylene, and styrene (Figure 11). They found that polyurethane fibers containing $30 \mathrm{wt} \% \mathrm{FA}$ had the smallest fiber diameter and the maximum specific surface area, it results in the highest VOCs adsorption capacity compared to other fibrous membranes. Furthermore, the adsorption of VOCs by fibrous membranes was in the following order: styrene $>$ xylene $>$ toluene $>$ benzene $>$ chloroform. This is because adsorption of VOCs by membranes not only depends on the surface area and fiber diameter, but also on other characteristics, including molecular polarity, molecular structure, molecular weight, pore size, porosity, chemical functional groups electronic and steric effects, $\pi$-complexes, adsorption kinetics, ionization potential, dipole moment, boiling point, temperature and humidity [104,124-127]. Other researchers have reported similar results [128-130]. In general, the less ionization potential aromatic compounds are easier to be absorbed by FA fibrous membranes due to their instability [131]. And the adsorbent with high $\mathrm{C} / \mathrm{O}$ ratio has the high adsorption capacity for adsorption of nonpolar VOCs [132]. Use of FA fibrous membrane to adsorb VOCs from air is an innovative research, which provides a new idea for using FA fibrous membrane to filter air pollutants. As an emerging material, FA fibrous membrane can be modified into a variety of air filters with great development potential in the field of environmental pollution management.

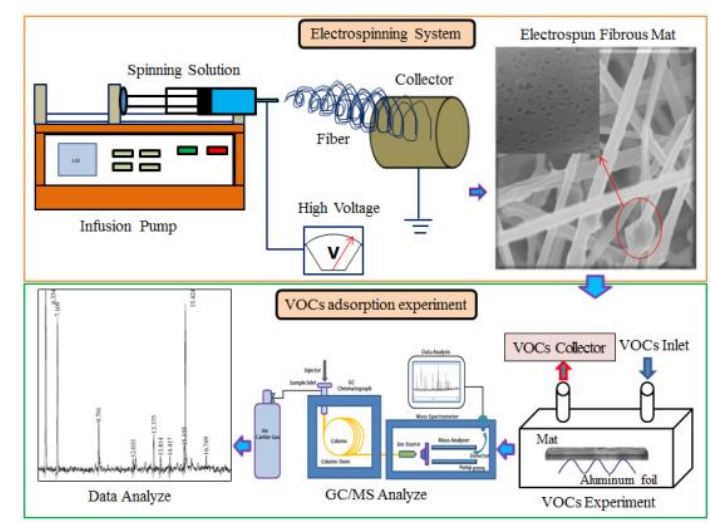

Figure 10. Schematic diagram of electrospun fibrous membrane and VOCs adsorption experiment. 

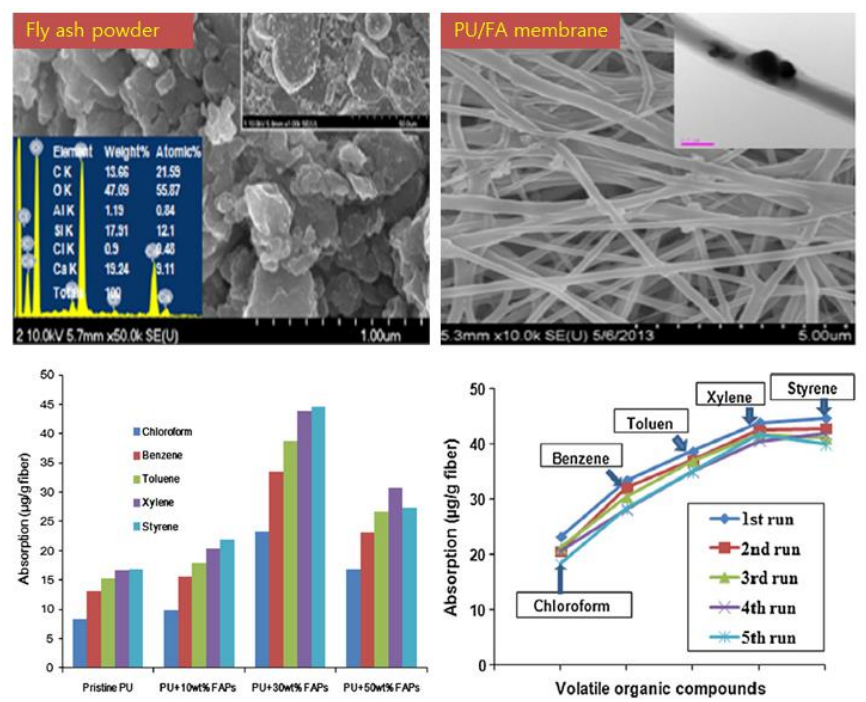

Figure 11. SEM images and VOCs adsorption capacity of FA membranes [33].

\subsubsection{Nitrogen oxides}

A small amount of NOx can be adsorbed by FA because of the unburned carbon in FA and the physical characteristics of FA such as high porosity and specific surface area $[133,134]$. In fact, this carbon is a precursor to activated carbon, but it has gone through devolatilization during combustion in the furnace of a power station [135]. Therefore, the internal carbon can be activated by some simple modifications to the FA to increase its adsorption capacity. The general method used is steam activation and physical separation, but because the ash content of carbon-enriched FA is too high, using chemical demineralization to activate carbon is the best method [136]. Rubio et al [136] studied adsorption of NOx by unburnt carbon from FA and found that the conversion curves of NO on different FA samples reached steady state after $10 \mathrm{~h}$. In addition, the enriched-carbon FA showed high NO abatement capacity due to increased carbon content, surface area, and porosity. Lzquierdo et al. [30] synthesized $\mathrm{Cu}$ and Fe exchange type $\mathrm{Y}$ zeolites from FA for removal of NOx from flue gas. Rubel et al. [137] also reported that carbon-rich products from combustion ash could decrease NOx emissions and $\mathrm{Hg}$ due to ion-pair interactions between $\mathrm{NO}^{+}$and $\mathrm{O}_{2}{ }^{-}$at the surface of carbon, with subsequent condensation of $\mathrm{NO}_{2}$ in micropores. In addition, the pore size on the surface of the adsorbent can be changed after adsorption of a certain amount of $\mathrm{Hg}$, producing the optimum pore size (micropores, $<2 \mathrm{~nm}$ ) for adsorbed NOx [138]. Rubel et al [137] also showed that the surface area of adsorbents increased due to adsorption of NOx, as shown in Figure 12. From the above literatures, it can be concluded that unburned carbon concentration in FA plays a decisive role for reducing NOx from air, and the high surface area of FA will further improve the NOx adsorption capacity.

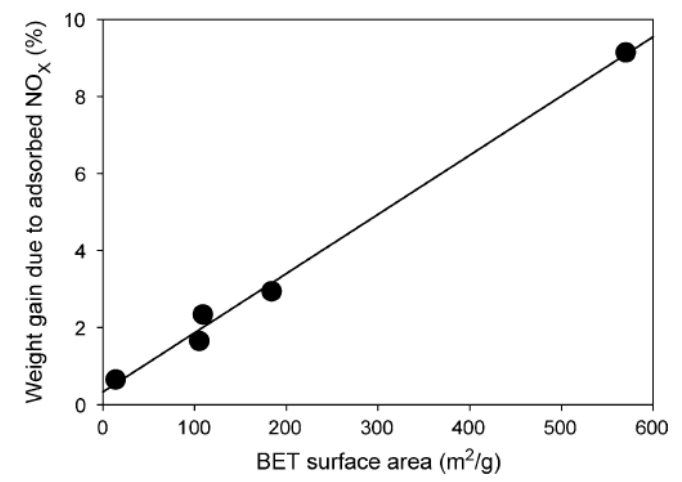

Figure 12. Relationship between BET surface area of adsorbent and adsorbed NOx [137].

\subsubsection{Sulfur dioxide}


Coal power generation plays an important role in electricity generation worldwide, accounting for about $41 \%$ of the world's power generation in 2006. In some countries, this percentage is even higher, such as Poland $(92 \%)$, China (79\%), and India (69\%) $[139,140]$. The large amount of coal used causes an increase in $\mathrm{SO}_{2}$ and a small amount of $\mathrm{SO}_{3}$, which pollute the air. $\mathrm{SO}_{2}$ is the main chemical responsible for formation of acid rain [141-143]. In addition, $\mathrm{SO}_{2}$ and $\mathrm{SO}_{3}$ are harmful gases that contribute to formation of submicron acid particles that can penetrate human lungs and be absorbed into the bloodstream [144]. Many researchers have reported that blending FA with $\mathrm{Ca}(\mathrm{OH})_{2}$ or $\mathrm{CaO}$ can produce an adsorbent via a hydration process with a better $\mathrm{SO}_{2}$ reduction than that of hydrated lime [145-147]. Lee et al. [148] found similar results, as shown in Figure 13. An adsorbent composed of a mixture of $\mathrm{FA} / \mathrm{CaO} / \mathrm{CaSO}_{4}$ was successfully synthesized with a higher $\mathrm{SO}_{2}$ adsorption capacity than that of pure $\mathrm{FA}, \mathrm{CaSO}_{4}$, and $\mathrm{CaO}$, due to its larger specific surface area $\left(64.5 \mathrm{~m}^{2} / \mathrm{g}\right)$. In addition, all adsorbents did not exhibit any significant desulfurization activity. SEM images of adsorbent before and after $\mathrm{SO}_{2}$ adsorption are shown in Figure 14. The high density of pore structures on the surface of the adsorbent before adsorbing $\mathrm{SO}_{2}$ can be clearly seen. However, the pores disappear after adsorption of $\mathrm{SO}_{2}$, due to $\mathrm{SO}_{2}$ being converted into sulfate salts $\left(\mathrm{CaSO}_{4}\right)$ and covering the surface of the adsorbent. From the above results, it can be concluded that the ability of FA to capture $\mathrm{SO}_{2}$ is mainly related to its surface area, pore structures and calcium ion content. Specific surface area is increased after the FA is hydrated, leading to more calcium ions that can react with $\mathrm{SO}_{2}$ to produce $\mathrm{CaSO}_{4}[149,150]$.

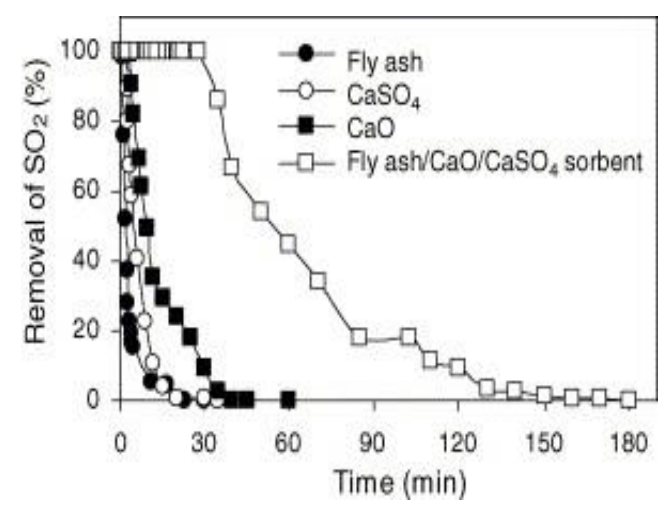

(a)

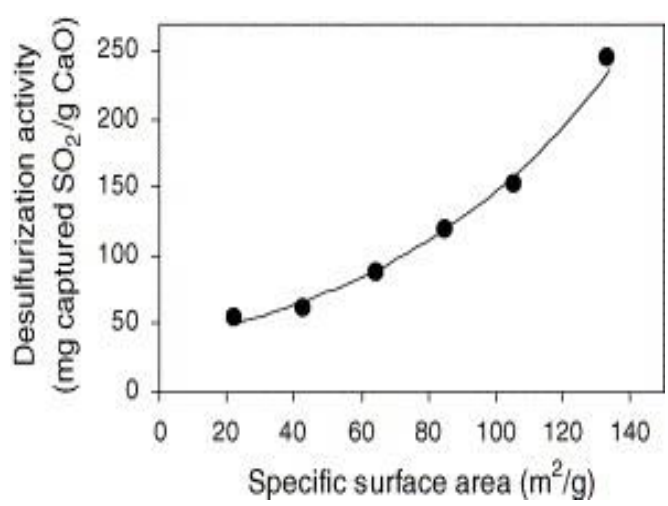

(b)

Figure 13. (a) Desulfurization activity of different adsorbents and (b) relationship between desulphurization capacity and specific surface area [148].
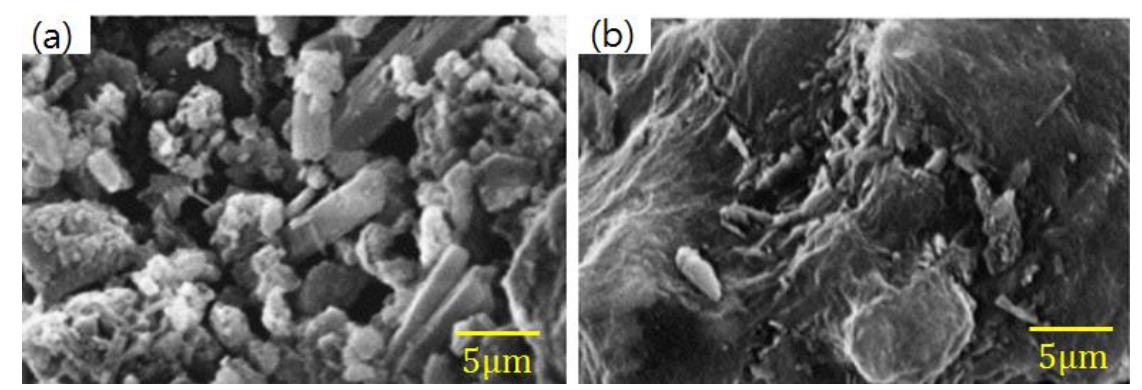

Figure 14. Comparison of SEM images before (a) and after (b) $\mathrm{SO}_{2}$ adsorption [148].

\subsection{Removing water pollutants}

Industrial development is likely to cause water pollution, especially heavy metal pollution, because of its inherent toxicity, large sources, persistence, non-degradability, and other factors and can cause serious harm to humans, animals, plants, and the environment [151,152]. Some of the common sources of anthropogenic heavy metals are displayed in Table 5 [153]. The treatment of waste water containing heavy metal can be divided into three categories: physical methods, chemical methods, and biological methods [5,154]. Physical methods include adsorption (activated carbon, carbon 
nanotubes, kaolinite and montmorillonite, FA, and other low-cost adsorbents), membrane filtration (ultrafiltration, reverse osmosis, nanofiltration, and electrodialysis), coagulation and flocculation, flotation, and other methods $[5,155]$. Chemical methods include chemical precipitation (hydroxide precipitation, sulfide precipitation, chelating precipitation, and chemical precipitation combined with other methods), ion-exchange, electrochemical treatment technologies, and others $[5,154]$. Biological methods include bio-adsorbents and use of microorganism, as well as others [156-158]. Among them, ion-exchange, adsorption and membrane filtration are the most commonly used method, and use of modified FA is an economical and efficient method for treatment of heavy metal wastewater because FA is derived from industrial waste.

FA can be used directly or indirectly (synthesized as zeolites) to adsorb heavy metal from polluted water $[159,160]$. And it is a potential adsorbent that can remove $\mathrm{Cu}, \mathrm{Pb}, \mathrm{Zn}, \mathrm{Mn}, \mathrm{Cd}, \mathrm{Cr}$, and $\mathrm{Ni}$ from wastewater $[161,162]$. On the other hand, the $\mathrm{pH}$ of the aqueous solution directly affects adsorption of metal ions due to changes in surface charge of the adsorbent and the degree of ionization $[159,163]$. FA has a high adsorption capacity for $\mathrm{Cu}^{2+}$ and $\mathrm{Zn}^{2+}$ ions at $\mathrm{pH}$ 8. In addition, using $\mathrm{FA}$ to adsorb $\mathrm{Cu}^{2+}$ and $\mathrm{Zn}^{2+}$ ions was faster than that of natural zeolite and peanut husk [164]. The SEM images of the FA before and after the adsorption of heavy metals are shown in Figure 15. As shown in Fig. 15b, it can be seen that the porosity between the FA particles is significantly reduced. This could be attributed to that the surface of FA is covered by complexes formed by heavy metal ions [163]. Moreover, FA has a stronger adsorption capacity for $\mathrm{Pb}^{2+}$ and $\mathrm{Cd}^{2+}$ than other heavy metal ions. Adsorption of $\mathrm{Pb}^{2+}$ and $\mathrm{Cd}^{2+}$ can be attributed to chemical sorption or chemisorption involving valence forces through sharing or exchange of electrons between the sorbent and sorbate, because their adsorption kinetics followed second-order reaction kinetics [163,165]. With the development of nanotechnology, FA can be fabricated into a functional fibrous membrane with a high capacity for adsorbing heavy metals [34]. FA particles can be perfectly combined with polyurethane fibers via electrospinning, and the FA fibrous membrane has higher adsorption capacity and faster adsorption rate for adsorption of $\mathrm{Pb}$ than that of $\mathrm{Hg}$. This is attributed to that the affinity of formation of $\mathrm{PbOH}^{+}$ is higher compared to $\mathrm{HgOH}^{+}[166,167]$. The results are encouraging for the removal of heavy metals using FA fibrous membrane from industrial wastewater. FA fibrous membrane can be used as a variety of filters with low-cost and high performance. These are a great help to improve the utilization of FA and reduce the pressure of environmental pollution. The mechanism of modified FA for treatment of heavy metal wastewater can be summarized as follows: most FA is alkaline with a high adsorption capacity and high surface area, and negative charge accumulates at the FA surface in alkaline solutions, FA can be expected to remove some metal ions from wastewater by electrostatic interactions or precipitation-adsorption; among them, the ion exchange capacity, high surface area, and unique pore characteristics of modified FA play an important role for treatment of heavy metal wastewater [6,154].
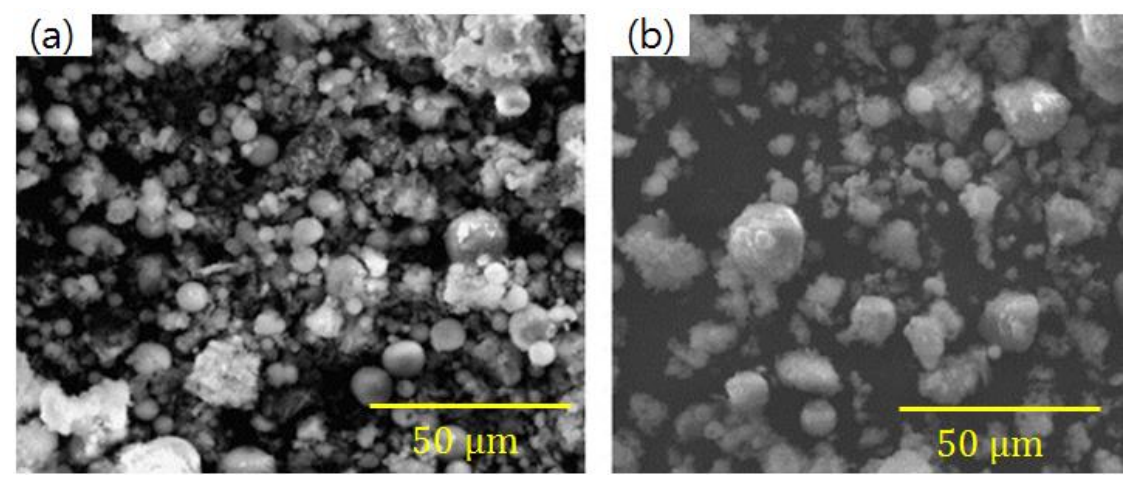

Figure 15. Comparison of SEM images before (a) and after (b) heavy metal adsorption [163].

Table 5. Common anthropogenic sources of heavy metals [153].

\begin{tabular}{lllllllll}
\hline Source & $\mathrm{As}$ & $\mathrm{Cd}$ & $\mathrm{Cr}$ & $\mathrm{Cu}$ & $\mathrm{Pb}$ & $\mathrm{Hg}$ & $\mathrm{Ni}$ & $\mathrm{Zn}$ \\
\hline
\end{tabular}




\begin{tabular}{cccccccccc}
\hline Mining \& ore processing & + & + & - & + & - & + & - & + \\
Metallurgy & + & + & + & + & + & + & + & + \\
Chemical industry & + & + & + & + & + & + & - & + \\
Alloys industry & - & - & - & - & + & - & - & - \\
Paint industry & - & + & + & - & + & - & - & + \\
Glass industry & + & - & - & - & + & + & - & - \\
Pulp and paper mills & - & - & + & + & + & + & + & - \\
Leather tanning & + & - & + & - & - & + & - & + \\
Textile dyeing \& printing & + & + & - & + & + & + & + & + \\
Chemical fertilizer industry & + & + & + & + & + & + & + & + \\
Chloro-alkali industry & + & + & + & - & + & + & - & + \\
Petroleum refining & + & + & + & + & + & + & - & + \\
Coal burning & + & + & + & + & + & + & + & - \\
\hline
\end{tabular}

\section{Conclusions}

Fly ash (FA) can be used as the base material of some adsorbents to treat air and water pollution due to its unique porous properties. In recent years, many experts in the field of environmental pollution control have studied FA. In this paper, the mechanism of FA for adsorption of air pollutants and water pollutants has been studied, in addition to a comparison of FA production of different countries, as well as the physical and chemical properties of FA. Detailed results are as follows:

i. Fly ash can be used in building materials, building works, roads construction, agriculture, and other fields.

ii. Fly ash can be converted to inexpensive and high performance adsorbents by simple modifications due to its unique porous properties. For example, is can be made into various kinds of zeolites.

iii. Modified fly ash has the ability to adsorb VOCs, $\mathrm{NOx}$ and $\mathrm{SO}_{2}$ emissions in the air and can also remove some heavy metals from wastewater, due to its high porosity, high surface area, appropriate pore size, high porosity, alkalinity, negative charge and other unique characteristics.

iv. Pristine fly ash is a powder, which limits its scope of use. Using nanotechnology, it can be synthesized into low-cost, multi-functional and multi-purpose porous hybrid composites for adsorption of air pollutants and water pollutants. Fly ash porous hybrid composites as an emerging material, which has great potential in the future.

Acknowledgments: This research was supported by the Basic Science Research Program through the National Research Foundation of Korea (NRF) funded by the Ministry of Education (Project No. 2016R1D1A1B03931616).

Author Contributions: Jun Cong Ge made suggestions, analyzed the physicochemical properties of fly ash, summarized the adsorption mechanism, and wrote this review paper. Sam Ki Yoon studied the synthetic methods of composite materials and their development trend. Nag Jung Choi guided the idea of the review paper, researched all of the data, and analyzed the application of nanocomposites in the control of environmental pollutants.

\section{References}

1. Deng, F.; Pan, Y.; Sun, W.; Yang, F.; Zhang, Y.; Huang, Z. An ignition delay time and chemical kinetic study of ethane sensitized by nitrogen dioxide. Fuel 2017, 207, 389-401.

2. Kampa, M.; Castanas, E. Human health effects of air pollution. Environmental Pollution 2008, 151, $362-$ 367. 
3. Bernstein, J.A.; Alexis, N.; Barnes, C.; Bernstein, I.L.; Nel, A.; Peden, D.; Diaz-Sanchez, D.; Tarlo, S.M.; Williams, P.B. Health effects of air pollution. Journal of allergy and clinical immunology 2004, 114, 11161123.

4. Zheng, N.; Liu, J.; Wang, Q.; Liang, Z. Health risk assessment of heavy metal exposure to street dust in the zinc smelting district, northeast of china. Science of The Total Environment 2010, 408, 726-733.

5. Ahmaruzzaman, M. A review on the utilization of fly ash. Progress in Energy and Combustion Science 2010, 36, 327-363.

6. Yao, Z.; Ji, X.; Sarker, P.; Tang, J.; Ge, L.; Xia, M.; Xi, Y. A comprehensive review on the applications of coal fly ash. Earth-Science Reviews 2015, 141, 105-121.

7. Bartoňová, L. Unburned carbon from coal combustion ash: An overview. Fuel Processing Technology 2015, 134, 136-158.

8. Ding, M.; Han, W.; Li, J.; Ma, E.; Shan, Z. In situ study of the mechanical properties of airborne haze particles. Science China Technological Sciences 2015, 58, 2046-2051.

9. $\quad$ Chen, S.; Xu, L.; Zhang, Y.; Chen, B.; Wang, X.; Zhang, X.; Zheng, M.; Chen, J.; Wang, W.; Sun, Y. Direct observations of organic aerosols in common wintertime hazes in north china: Insights into direct emissions from chinese residential stoves. Atmospheric Chemistry and Physics 2017, 17, 1259-1270.

10. Ge, J.C.; Yoon, S.K.; Choi, N.J. Using canola oil biodiesel as an alternative fuel in diesel engines: A review. Applied Sciences 2017, 7, 881.

11. Iyer, R.S.; Scott, J.A. Power station fly ash - a review of value-added utilization outside of the construction industry. Resources, Conservation and Recycling 2001, 31, 217-228.

12. Zhuang, X.Y.; Chen, L.; Komarneni, S.; Zhou, C.H.; Tong, D.S.; Yang, H.M.; Yu, W.H.; Wang, H. Fly ash-based geopolymer: Clean production, properties and applications. Journal of Cleaner Production 2016, 125, 253-267.

13. Park, J.H.; Edraki, M.; Mulligan, D.; Jang, H.S. The application of coal combustion by-products in mine site rehabilitation. Journal of Cleaner Production 2014, 84, 761-772.

14. Gupta, V.K.; Sharma, S. Removal of zinc from aqueous solutions using bagasse fly ash- a low cost adsorbent. Industrial \& engineering chemistry research 2003, 42, 6619-6624.

15. Bouzoubaa, N.; Lachemi, M. Self-compacting concrete incorporating high volumes of class $\mathrm{f}$ fly ash: Preliminary results. Cement and concrete research 2001, 31, 413-420.

16. Abbas, S.; Saleem, M.A.; Kazmi, S.M.; Munir, M.J. Production of sustainable clay bricks using waste fly ash: Mechanical and durability properties. Journal of Building Engineering 2017, 14, 7-14.

17. Kumar, S. Fly ash-lime-phosphogypsum hollow blocks for walls and partitions. Building and Environment 2003, 38, 291-295.

18. Dilmore, R.M.; Neufeld, R.D. Autoclaved aerated concrete produced with low no $x$ burner/selective catalytic reduction fly ash. Journal of energy engineering 2001, 127, 37-50.

19. del Valle-Zermeño, R.; Formosa, J.; Chimenos, J.; Martínez, M.; Fernández, A. Aggregate material formulated with mswi bottom ash and apc fly ash for use as secondary building material. Waste management 2013, 33, 621-627.

20. Kumar, S. A perspective study on fly ash-lime-gypsum bricks and hollow blocks for low cost housing development. Construction and Building Materials 2002, 16, 519-525.

21. Andini, S.; Cioffi, R.; Colangelo, F.; Grieco, T.; Montagnaro, F.; Santoro, L. Coal fly ash as raw material for the manufacture of geopolymer-based products. Waste management 2008, 28, 416-423. 
22. Jala, S.; Goyal, D. Fly ash as a soil ameliorant for improving crop production-a review. Bioresource Technology 2006, 97, 1136-1147.

23. Basu, M.; Pande, M.; Bhadoria, P.; Mahapatra, S. Potential fly-ash utilization in agriculture: A global review. Progress in Natural Science 2009, 19, 1173-1186.

24. Ram, L.; Srivastava, N.; Tripathi, R.; Jha, S.; Sinha, A.K.; Singh, G.; Manoharan, V. Management of mine spoil for crop productivity with lignite fly ash and biological amendments. Journal of environmental management 2006, 79, 173-187.

25. Rao, M.; Parwate, A.; Bhole, A. Removal of cr6+ and ni2+ from aqueous solution using bagasse and fly ash. Waste management 2002, 22, 821-830.

26. Bayat, B. Comparative study of adsorption properties of turkish fly ashes: I. The case of nickel (ii), copper (ii) and zinc (ii). Journal of hazardous materials 2002, 95, 251-273.

27. Ram, L.C.; Srivastava, N.K.; Tripathi, R.C.; Thakur, S.K.; Sinha, A.K.; Jha, S.K.; Masto, R.E.; Mitra, S. Leaching behavior of lignite fly ash with shake and column tests. Environmental Geology 2007, 51, 11191132.

28. Bhattacharyya, A.; Kerketta, S.; Kumar, M.S.; Rajanikanth, B. In Discharge plasma cascaded with fly ash for removal of nox in biodiesel exhaust: A feasibility study, Int'l. Sympos. Non-Thermal/Thermal Plasma Pollution Control Technology and Sustainable Energy, 2014; pp I-IV.

29. Hower, J.C.; Maroto-Valer, M.M.; Taulbee, D.N.; Sakulpitakphon, T. Mercury capture by distinct fly ash carbon forms. Energy \& Fuels 2000, 14, 224-226.

30. Izquierdo, M.; Rubio, B. Carbon-enriched coal fly ash as a precursor of activated carbons for so2 removal. Journal of hazardous materials 2008, 155, 199-205.

31. Zhou, L.; Chen, Y.-L.; Zhang, X.-H.; Tian, F.-M.; Zu, Z.-N. Zeolites developed from mixed alkali modified coal fly ash for adsorption of volatile organic compounds. Materials Letters 2014, 119, 140-142.

32. Kim, H.J.; Pant, H.R.; Choi, N.J.; Kim, C.S. Fly ash/polyurethane thin film for the adsorption of volatile organic compounds (vocs) from air. Fibers and Polymers 2014, 15, 1393-1398.

33. Kim, H.J.; Pant, H.R.; Choi, N.J.; Kim, C.S. Composite electrospun fly ash/polyurethane fibers for absorption of volatile organic compounds from air. Chemical engineering journal 2013, 230, 244-250.

34. Joo Kim, H.; Raj Pant, H.; Hee Kim, J.; Jung Choi, N.; Sang Kim, C. Fabrication of multifunctional tio2fly ash/polyurethane nanocomposite membrane via electrospinning. Ceramics International 2014, 40, 3023-3029.

35. Pant, H.R.; Kim, H.J.; Joshi, M.K.; Pant, B.; Park, C.H.; Kim, J.I.; Hui, K.; Kim, C.S. One-step fabrication of multifunctional composite polyurethane spider-web-like nanofibrous membrane for water purification. Journal of hazardous materials 2014, 264, 25-33.

36. Xu, J.; Zhou, M.; Li, H. The drag effect of coal consumption on economic growth in china during 19532013. Resources, Conservation and Recycling 2018, 129, 326-332.

37. He, Y.; Luo, Q.; Hu, H. Situation analysis and countermeasures of china's fly ash pollution prevention and control. Procedia Environmental Sciences 2012, 16, 690-696.

38. Dong, P.; Wang, S.Y. In Risks and countermeasures of the shale gas development in china, Advanced Materials Research, 2013; Trans Tech Publ: pp 1253-1256.

39. $\mathrm{Hu}, \mathrm{D} . ; \mathrm{Xu}, \mathrm{S}$. Opportunity, challenges and policy choices for china on the development of shale gas. Energy Policy 2013, 60, 21-26.

40. Pi, G.; Dong, X.; Dong, C.; Guo, J.; Ma, Z. The status, obstacles and policy recommendations of shale gas development in china. Sustainability 2015, 7, 2353-2372. 
41. Yao, Z.; Xia, M.; Sarker, P.K.; Chen, T. A review of the alumina recovery from coal fly ash, with a focus in china. Fuel 2014, 120, 74-85.

42. Wang, C.; Li, J.; Wang, L.; Sun, X. Study on adsorption of cr (vi) using singlephase zeolites synthesized from fly ash. Chin J Environ Eng 2008, 2, 1121-1126.

43. Ram, L.; Masto, R. Fly ash for soil amelioration: A review on the influence of ash blending with inorganic and organic amendments. Earth-Science Reviews 2014, 128, 52-74.

44. Aslam, Z.; Shawabkeh, R.A.; Hussein, I.A.; Al-Baghli, N.; Eic, M. Synthesis of activated carbon from oil fly ash for removal of h2s from gas stream. Applied Surface Science 2015, 327, 107-115.

45. Lo, T.Y.; Cui, H.; Memon, S.A.; Noguchi, T. Manufacturing of sintered lightweight aggregate using high-carbon fly ash and its effect on the mechanical properties and microstructure of concrete. Journal of Cleaner Production 2016, 112, 753-762.

46. Chun-xiang, G.; Shuai, L. Environmental pollution and comprehensive utilization of fly ash. Shanghai Environmental Science 2004, 23, 182-184.

47. Bhattacharjee, U.; Kandpal, T.C. Potential of fly ash utilisation in india. Energy 2002, 27, 151-166.

48. 6th fly ash utilisation. http://cbrienvis.nic.in/FAU\%20-\%202017.pdf

49. Singh, R.; Gupta, N. Value added utilization of fly ash-prospective and sustainable solutions. International Journal of Applied Science and Engineering Research 2014, 3, 1-16.

50. Parab, N.; Mishra, S.; Bhonde, S. Prospects of bulk utilization of fly ash in agriculture for integrated nutrient management. Bulletin of the National Institute of Ecology 2012, 23, 31-46.

51. Kalra, N.; Harit, R.; Sharma, S. Effect of flyash incorporation on soil properties of texturally variant soils. Bioresource Technology 2000, 75, 91-93.

52. Yeledhalli, N.; Prakash, S.; Gurumurthy, S.; Ravi, M. Coal fly ash as modifier of physico-chemical and biological properties of soil. Karnataka Journal of Agricultural Sciences 2010, 20.

53. Garg, R.N.; Pathak, H.; Das, D.; Tomar, R. Use of flyash and biogas slurry for improving wheat yield and physical properties of soil. Environmental Monitoring and Assessment 2005, 107, 1-9.

54. Dhadse, S.; Kumari, P.; Bhagia, L. Fly ash characterization, utilization and government initiatives in india œ a review. 2008.

55. Dermatas, D.; Meng, X. Utilization of fly ash for stabilization/solidification of heavy metal contaminated soils. Engineering Geology 2003, 70, 377-394.

56. Production and use of coal combustion products in the u.S. https://www.acaausa.org/Portals/9/Files/PDFs/ReferenceLibrary/ARTBA-final-historical.compressed.pdf

57. U.S. Energy facts explained_eia. https://www.eia.gov/energyexplained/?page=us energy home

58. Half of power plant capacity additions in 2013 came from natural gas_eia. https://www.eia.gov/todayinenergy/detail.php?id=15751

59. Kishor, P.; Ghosh, A.; Kumar, D. Use of flyash in agriculture: A way to improve soil fertility and its productivity. Asian Journal of Agricultural Research 2010, 4, 1-14.

60. Nyambura, M.G.; Mugera, G.W.; Felicia, P.L.; Gathura, N.P. Carbonation of brine impacted fractionated coal fly ash: Implications for co2 sequestration. Journal of environmental management 2011, 92, 655-664.

61. Kalaw, M.E.; Culaba, A.; Hinode, H.; Kurniawan, W.; Gallardo, S.; Promentilla, M.A. Optimizing and characterizing geopolymers from ternary blend of philippine coal fly ash, coal bottom ash and rice hull ash. Materials 2016, 9, 580 .

62. Matsunaga, T.; Kim, J.; Hardcastle, S.; Rohatgi, P. Crystallinity and selected properties of fly ash particles. Materials Science and Engineering: A 2002, 325, 333-343. 
63. Safiuddin, M.; Jumaat, M.Z.; Salam, M.; Islam, M.; Hashim, R. Utilization of solid wastes in construction materials. International Journal of Physical Sciences 2010, 5, 1952-1963.

64. Messina, F.; Ferone, C.; Colangelo, F.; Cioffi, R. Low temperature alkaline activation of weathered fly ash: Influence of mineral admixtures on early age performance. Construction and Building Materials 2015, $86,169-177$.

65. Cao, J.; Dong, X.; Li, L.; Dong, Y.; Hampshire, S. Recycling of waste fly ash for production of porous mullite ceramic membrane supports with increased porosity. Journal of the European Ceramic Society 2014, 34, 3181-3194.

66. Yang, T.; Ji, H.; Yoon, S.; Kim, B.; Park, H. Porous mullite composite with controlled pore structure processed using a freeze casting of tba-based coal fly ash slurries. Resources, Conservation and Recycling 2010, 54, 816-820.

67. Kutchko, B.G.; Kim, A.G. Fly ash characterization by sem-eds. Fuel 2006, 85, 2537-2544.

68. Külaots, I.; Hurt, R.H.; Suuberg, E.M. Size distribution of unburned carbon in coal fly ash and its implications. Fuel 2004, 83, 223-230.

69. Zhu, Z.; Wang, X.; Dai, S.; Huang, B.; He, Q. Fractional characteristics of coal fly ash for beneficial use. Journal of Materials in Civil Engineering 2012, 25, 63-69.

70. Vassilev, S.V.; Menendez, R.; Alvarez, D.; Diaz-Somoano, M.; Martinez-Tarazona, M.R. Phase-mineral and chemical composition of coal fly ashes as a basis for their multicomponent utilization. 1. Characterization of feed coals and fly ashes is. Fuel 2003, 82, 1793-1811.

71. Vassilev, S.V.; Menendez, R. Phase-mineral and chemical composition of coal fly ashes as a basis for their multicomponent utilization. 4. Characterization of heavy concentrates and improved fly ash residues. Fuel 2005, 84, 973-991.

72. Vassilev, S.V.; Vassileva, C.G. Methods for characterization of composition of fly ashes from coal-fired power stations: A critical overview. Energy \& Fuels 2005, 19, 1084-1098.

73. Sarode, D.B.; Jadhav, R.N.; Khatik, V.A.; Ingle, S.T.; Attarde, S.B. Extraction and leaching of heavy metals from thermal power plant fly ash and its admixtures. Polish J. Environ. Stud 2010, 6, 1325-1330.

74. Park, Y.J.; Heo, J. Vitrification of fly ash from municipal solid waste incinerator. Journal of Hazardous Materials 2002, 91, 83-93.

75. Polat, H.; Vengosh, A.; Pankratov, I.; Polat, M. A new methodology for removal of boron from water by coal and fly ash. Desalination 2004, 164, 173-188.

76. JIANG, J.-g.; Xin, X.; Jun, W.; YANG, S.-j.; ZHANG, Y. Investigation of basic properties of fly ash from urban waste incinerators in china. Journal of Environmental Sciences 2007, 19, 458-463.

77. Sushil, S.; Batra, V.S. Analysis of fly ash heavy metal content and disposal in three thermal power plants in india. Fuel 2006, 85, 2676-2679.

78. Fan, M.; Brown, R.C. Comparison of the loss-on-ignition and thermogravimetric analysis techniques in measuring unburned carbon in coal fly ash. Energy $\mathcal{E}$ fuels 2001, 15, 1414-1417.

79. Mangialardi, T. Sintering of msw fly ash for reuse as a concrete aggregate. Journal of Hazardous Materials 2001, 87, 225-239.

80. Querol, X.; Umaña, J.C.; Plana, F.; Alastuey, A.; Lopez-Soler, A.; Medinaceli, A.; Valero, A.; Domingo, M.J.; Garcia-Rojo, E. Synthesis of zeolites from fly ash at pilot plant scale. Examples of potential applications. Fuel 2001, 80, 857-865.

81. Inada, M.; Tsujimoto, H.; Eguchi, Y.; Enomoto, N.; Hojo, J. Microwave-assisted zeolite synthesis from coal fly ash in hydrothermal process. Fuel 2005, 84, 1482-1486. 
82. Fernández-Jiménez, A.; Palomo, A. Mid-infrared spectroscopic studies of alkali-activated fly ash structure. Microporous and Mesoporous Materials 2005, 86, 207-214.

83. Wang, S.; Boyjoo, Y.; Choueib, A.; Zhu, Z. Removal of dyes from aqueous solution using fly ash and red mud. Water research 2005, 39, 129-138.

84. Montes-Hernandez, G.; Perez-Lopez, R.; Renard, F.; Nieto, J.; Charlet, L. Mineral sequestration of co2 by aqueous carbonation of coal combustion fly-ash. Journal of hazardous Materials 2009, 161, 1347-1354.

85. Bertos, M.F.; Li, X.; Simons, S.; Hills, C.; Carey, P. Investigation of accelerated carbonation for the stabilisation of msw incinerator ashes and the sequestration of co 2. Green Chemistry 2004, 6, 428-436.

86. Ramezanianpour, A.A. Cement replacement materials. Springer-Verlag Berlin Heidelberg: 2014; p XIII, 336.

87. Ge, J.C.; Kim, H.Y.; Yoon, S.K.; Choi, N.J. Reducing volatile organic compound emissions from diesel engines using canola oil biodiesel fuel and blends. Fuel 2018, 218, 266-274.

88. Yilmaz, N.; Davis, S.M. Polycyclic aromatic hydrocarbon (pah) formation in a diesel engine fueled with diesel, biodiesel and biodiesel/n-butanol blends. Fuel 2016, 181, 729-740.

89. Li, G.; Wei, W.; Shao, X.; Nie, L.; Wang, H.; Yan, X.; Zhang, R. A comprehensive classification method for voc emission sources to tackle air pollution based on voc species reactivity and emission amounts. Journal of Environmental Sciences 2017.

90. Malakar, S.; Saha, P.D.; Baskaran, D.; Rajamanickam, R. Comparative study of biofiltration process for treatment of vocs emission from petroleum refinery wastewater-a review. Environmental Technology E Innovation 2017.

91. Lee, S.; Lam, S.; Fai, H.K. Characterization of vocs, ozone, and pm10 emissions from office equipment in an environmental chamber. Building and Environment 2001, 36, 837-842.

92. Atkinson, R. Atmospheric chemistry of vocs and nox. Atmospheric environment 2000, 34, $2063-2101$.

93. Sakai, N.; Yamamoto, S.; Matsui, Y.; Khan, M.F.; Latif, M.T.; Mohd, M.A.; Yoneda, M. Characterization and source profiling of volatile organic compounds in indoor air of private residences in selangor state, malaysia. Science of the Total Environment 2017, 586, 1279-1286.

94. Ge, J.C.; Choi, N.J. Fabrication of functional polyurethane/rare earth nanocomposite membranes by electrospinning and its vocs absorption capacity from air. Nanomaterials 2017, 7, 60.

95. Mendell, M.J. Indoor residential chemical emissions as risk factors for respiratory and allergic effects in children: A review. Indoor air 2007, 17, 259-277.

96. Kim, H.-J.; Yoon, J.-W.; Choi, K.-I.; Jang, H.W.; Umar, A.; Lee, J.-H. Ultraselective and sensitive detection of xylene and toluene for monitoring indoor air pollution using cr-doped nio hierarchical nanostructures. Nanoscale 2013, 5, 7066-7073.

97. Rayalu, S.; Meshram, S.; Biniwale, R.B.; Srivasatava, A.; Jadhav, P.; Devotta, S. Volatile organic carbon monitoring in indoor environment using a versatile hydrophobic flyash-based zeolite as adsorbent. Current Science 2006, 497-503.

98. Guo, H.; Lee, S.; Li, W.; Cao, J. Source characterization of btex in indoor microenvironments in hong kong. Atmospheric Environment 2003, 37, 73-82.

99. Kim, S.C.; Nahm, S.W.; Shim, W.G.; Lee, J.W.; Moon, H. Influence of physicochemical treatments on spent palladium based catalyst for catalytic oxidation of vocs. Journal of Hazardous Materials 2007, 141, 305-314. 
100. Barna, M.; Lamb, B.; Westberg, H. Modeling the effects of voc/nox emissions on ozone synthesis in the cascadia airshed of the pacific northwest. Journal of the Air E Waste Management Association 2001, 51, 1021-1034.

101. Kim, M.J.; Park, R.J.; Kim, J.-J. Urban air quality modeling with full o3-nox-voc chemistry: Implications for 03 and pm air quality in a street canyon. Atmospheric Environment 2012, 47, 330-340.

102. Shao, M.; Zhang, Y.; Zeng, L.; Tang, X.; Zhang, J.; Zhong, L.; Wang, B. Ground-level ozone in the pearl river delta and the roles of voc and nox in its production. Journal of Environmental Management 2009, 90, 512-518.

103. Wei, W.; Cheng, S.; Li, G.; Wang, G.; Wang, H. Characteristics of ozone and ozone precursors (vocs and nox) around a petroleum refinery in beijing, china. Journal of Environmental Sciences 2014, 26, 332-342.

104. Zhang, X.; Gao, B.; Creamer, A.E.; Cao, C.; Li, Y. Adsorption of vocs onto engineered carbon materials: A review. Journal of hazardous materials 2017, 338, 102-123.

105. Seo, J.; Kato, S.; Ataka, Y.; Chino, S. Performance test for evaluating the reduction of vocs in rooms and evaluating the lifetime of sorptive building materials. Building and environment 2009, 44, 207-215.

106. Chmielewski, A.; Ostapczuk, A.; Zimek, Z.; Licki, J.; Kubica, K. Reduction of vocs in flue gas from coal combustion by electron beam treatment. Radiation Physics and Chemistry 2002, 63, 653-655.

107. Kim, S. The reduction of formaldehyde and vocs emission from wood-based flooring by green adhesive using cashew nut shell liquid (cnsl). Journal of hazardous materials 2010, 182, 919-922.

108. Suresh, S.; Vijayalakshmi, G.; Rajmohan, B.; Subbaramaiah, V. Adsorption of benzene vapor onto activated biomass from cashew nut shell: Batch and column study. Recent Patents on Chemical Engineering 2012, 5, 116-133.

109. Tseng, T.K.; Lin, Y.S.; Chen, Y.J.; Chu, H. A review of photocatalysts prepared by sol-gel method for vocs removal. International journal of molecular sciences 2010, 11, 2336-2361.

110. Parker, D. Reduction of odor and voc emissions from a dairy lagoon. Applied engineering in agriculture 2008, 24, 647-655.

111. Hu, C.; Zhu, Q.; Jiang, Z.; Zhang, Y.; Wang, Y. Preparation and formation mechanism of mesoporous cuo-ceo2 mixed oxides with excellent catalytic performance for removal of vocs. Microporous and Mesoporous Materials 2008, 113, 427-434.

112. Belkouch, J.; Ould-Dris, A.; Taouk, B. Removal of hazardous chlorinated vocs over mn-cu mixed oxide based catalyst. Journal of hazardous materials 2009, 169, 758-765.

113. Kim, S.C.; Shim, W.G. Catalytic combustion of vocs over a series of manganese oxide catalysts. Applied Catalysis B: Environmental 2010, 98, 180-185.

114. Scire, S.; Minico, S.; Crisafulli, C.; Satriano, C.; Pistone, A. Catalytic combustion of volatile organic compounds on gold/cerium oxide catalysts. Applied Catalysis B: Environmental 2003, 40, 43-49.

115. Liotta, L. Catalytic oxidation of volatile organic compounds on supported noble metals. Applied Catalysis B: Environmental 2010, 100, 403-412.

116. Chuang, C.; Chiang, P.; Chang, E. Modeling vocs adsorption onto activated carbon. Chemosphere 2003, 53, 17-27.

117. Chiang, Y.-C.; Chiang, P.-C.; Huang, C.-P. Effects of pore structure and temperature on voc adsorption on activated carbon. Carbon 2001, 39, 523-534.

118. Li, L.; Liu, S.; Liu, J. Surface modification of coconut shell based activated carbon for the improvement of hydrophobic voc removal. Journal of hazardous materials 2011, 192, 683-690. 
119. Das, D.; Gaur, V.; Verma, N. Removal of volatile organic compound by activated carbon fiber. Carbon 2004, 42, 2949-2962.

120. Tsai, J.-H.; Chiang, H.-M.; Huang, G.-Y.; Chiang, H.-L. Adsorption characteristics of acetone, chloroform and acetonitrile on sludge-derived adsorbent, commercial granular activated carbon and activated carbon fibers. Journal of hazardous materials 2008, 154, 1183-1191.

121. Oh, G.-Y.; Ju, Y.-W.; Jung, H.-R.; Lee, W.-J. Preparation of the novel manganese-embedded pan-based activated carbon nanofibers by electrospinning and their toluene adsorption. Journal of Analytical and Applied Pyrolysis 2008, 81, 211-217.

122. Bai, Y.; Huang, Z.-H.; Kang, F. Synthesis of reduced graphene oxide/phenolic resin-based carbon composite ultrafine fibers and their adsorption performance for volatile organic compounds and water. Journal of Materials Chemistry A 2013, 1, 9536-9543.

123. Liu, Y.; Hou, C.; Jiao, T.; Song, J.; Zhang, X.; Xing, R.; Zhou, J.; Zhang, L.; Peng, Q. Self-assembled agnpcontaining nanocomposites constructed by electrospinning as efficient dye photocatalyst materials for wastewater treatment. Nanomaterials 2018, 8, 35.

124. Ahmaruzzaman, M.; Gupta, V. Application of coal fly ash in air quality management. Industrial $\mathcal{E}$ Engineering Chemistry Research 2012, 51, 15299-15314.

125. Lee, S.-B.; Chung, K.-W.; Hong, I.-K.; Kim, H.-J. Selective catalytic oxidation of volatile organic solvent mixtures. Journal of Industrial and Engineering Chemistry 2001, 7, 193-198.

126. Qian, Q.; Gong, C.; Zhang, Z.; Yuan, G. Removal of vocs by activated carbon microspheres derived from polymer: A comparative study. Adsorption 2015, 21, 333-341.

127. Guo, Y.; Li, Y.; Zhu, T.; Ye, M. Effects of concentration and adsorption product on the adsorption of so2 and no on activated carbon. Energy \& Fuels 2012, 27, 360-366.

128. Baur, G.B.; Yuranov, I.; Renken, A.; Kiwi-Minsker, L. Activated carbon fibers for efficient voc removal from diluted streams: The role of surface morphology. Adsorption 2015, 21, 479-488.

129. Lillo-Ródenas, M.; Cazorla-Amorós, D.; Linares-Solano, A. Behaviour of activated carbons with different pore size distributions and surface oxygen groups for benzene and toluene adsorption at low concentrations. Carbon 2005, 43, 1758-1767.

130. Ju, Y.-W.; Oh, G.-Y. Behavior of toluene adsorption on activated carbon nanofibers prepared by electrospinning of a polyacrylonitrile-cellulose acetate blending solution. Korean Journal of Chemical Engineering 2017, 34, 2731-2737.

131. Shim, W.G.; Kim, S.C. Heterogeneous adsorption and catalytic oxidation of benzene, toluene and xylene over spent and chemically regenerated platinum catalyst supported on activated carbon. Applied Surface Science 2010, 256, 5566-5571.

132. Huang, Z.-H.; Kang, F.; Zheng, Y.-P.; Yang, J.-B.; Liang, K.-M. Adsorption of trace polar methy-ethylketone and non-polar benzene vapors on viscose rayon-based activated carbon fibers. Carbon 2002, 40, 1363-1367.

133. Davini, P. Flue gas treatment by activated carbon obtained from oil-fired fly ash. Carbon 2002, 40, 19731979.

134. Wang, W.; Zhao, Z.; Liu, F.; Wang, S. Study of no/nox removal from flue gas contained fly ash and water vapor by pulsed corona discharge. Journal of Electrostatics 2005, 63, 155-164.

135. Rokni, E.; Panahi, A.; Ren, X.; Levendis, Y.A. Curtailing the generation of sulfur dioxide and nitrogen oxide emissions by blending and oxy-combustion of coals. Fuel 2016, 181, 772-784. 
136. Rubio, B.; Izquierdo, M.T.; Mayoral, M.C.; Bona, M.T.; Andres, J.M. Unburnt carbon from coal fly ashes as a precursor of activated carbon for nitric oxide removal. Journal of hazardous materials 2007, 143, 561566.

137. Rubel, A.; Andrews, R.; Gonzalez, R.; Groppo, J.; Robl, T. Adsorption of hg and nox on coal by-products. Fuel 2005, 84, 911-916.

138. Hwang, J.; Sun, X.; Li, Z. Unburned carbon from fly ash for mercury adsorption: I. Separation and characterization of unburned carbon. Journal of Minerals and Materials Characterization and Engineering 2002, 1, 39.

139. Mehmood, S.; Reddy, B.V.; Rosen, M.A. Energy analysis of a biomass co-firing based pulverized coal power generation system. Sustainability 2012, 4, 462-490.

140. Bukhari, S.S.; Behin, J.; Kazemian, H.; Rohani, S. Conversion of coal fly ash to zeolite utilizing microwave and ultrasound energies: A review. Fuel 2015, 140, 250-266.

141. Zhang, H.; Zhang, B.; Bi, J. More efforts, more benefits: Air pollutant control of coal-fired power plants in china. Energy 2015, 80, 1-9.

142. Long, X.-L.; Xin, Z.-L.; Wang, H.-X.; Xiao, W.-D.; Yuan, W.-K. Simultaneous removal of no and so2 with hexamminecobalt (ii) solution coupled with the hexamminecobalt (ii) regeneration catalyzed by activated carbon. Applied Catalysis B: Environmental 2004, 54, 25-32.

143. Liu, Y.x.; Zhang, J. Photochemical oxidation removal of no and so2 from simulated flue gas of coal-fired power plants by wet scrubbing using uv/h2o2 advanced oxidation process. Industrial E Engineering Chemistry Research 2011, 50, 3836-3841.

144. Srivastava, R.; Miller, C.; Erickson, C.; Jambhekar, R. Emissions of sulfur trioxide from coal-fired power plants. Journal of the Air \& Waste Management Association 2004, 54, 750-762.

145. Ishizuka, T.; Tsuchiai, H.; Murayama, T.; Tanaka, T.; Hattori, H. Preparation of active absorbent for drytype flue gas desulfurization from calcium oxide, coal fly ash, and gypsum. Industrial $\mathcal{E}$ engineering chemistry research 2000, 39, 1390-1396.

146. Renedo, M.; Fernandez, J. Preparation, characterization, and calcium utilization of fly ash/ca (oh) 2 sorbents for dry desulfurization at low temperature. Industrial \& engineering chemistry research 2002, 41, 2412-2417.

147. Lin, R.-B.; Shih, S.-M.; Liu, C.-F. Characteristics and reactivities of ca (oh) 2/silica fume sorbents for lowtemperature flue gas desulfurization. Chemical Engineering Science 2003, 58, 3659-3668.

148. Lee, K.; Mohamed, A.; Bhatia, S.; Chu, K. Removal of sulfur dioxide by fly ash/cao/caso4 sorbents. Chemical engineering journal 2005, 114, 171-177.

149. Lee, K.T.; Bhatia, S.; Mohamed, A.R. Preparation and characterization of sorbents prepared from ash (waste material) for sulfur dioxide (so 2) removal. Journal of material cycles and waste management 2005, 7, 16-23.

150. Lin, R.-B.; Shih, S.-M.; Liu, C.-F. Structural properties and reactivities of ca (oh) 2/fly ash sorbents for flue gas desulfurization. Industrial $\mathcal{E}$ engineering chemistry research 2003, 42, 1350-1356.

151. Duruibe, J.; Ogwuegbu, M.; Egwurugwu, J. Heavy metal pollution and human biotoxic effects. International Journal of physical sciences 2007, 2, 112-118.

152. Wang, S.-L.; Xu, X.-R.; Sun, Y.-X.; Liu, J.-L.; Li, H.-B. Heavy metal pollution in coastal areas of south china: A review. Marine pollution bulletin 2013, 76, 7-15.

153. Agarwal, S.K. Heavy metal pollution. APH publishing: 2009; Vol. 4. 
154. Fu, F.; Wang, Q. Removal of heavy metal ions from wastewaters: A review. Journal of Environmental Management 2011, 92, 407-418.

155. Bieseki, L.; Penha, F.G.; Pergher, S.B.C. Zeolite a synthesis employing a brazilian coal ash as the silicon and aluminum source and its applications in adsorption and pigment formulation. Materials Research 2013, 16, 38-43.

156. Huisman, J.L.; Schouten, G.; Schultz, C. Biologically produced sulphide for purification of process streams, effluent treatment and recovery of metals in the metal and mining industry. Hydrometallurgy 2006, 83, 106-113.

157. Mirbagheri, S.; Hosseini, S. Pilot plant investigation on petrochemical wastewater treatmentfor the removal of copper and chromium with the objective of reuse. Desalination 2005, 171, 85-93.

158. Özverdi, A.; Erdem, M. Cu2+, cd2+ and pb2+ adsorption from aqueous solutions by pyrite and synthetic iron sulphide. Journal of hazardous materials 2006, 137, 626-632.

159. Cho, H.; Oh, D.; Kim, K. A study on removal characteristics of heavy metals from aqueous solution by fly ash. Journal of Hazardous Materials 2005, 127, 187-195.

160. Hui, K.; Chao, C.Y.H.; Kot, S. Removal of mixed heavy metal ions in wastewater by zeolite 4a and residual products from recycled coal fly ash. Journal of Hazardous Materials 2005, 127, 89-101.

161. Babel, S.; Kurniawan, T.A. Low-cost adsorbents for heavy metals uptake from contaminated water: A review. Journal of hazardous materials 2003, 97, 219-243.

162. Weng, C.-H.; Huang, C. Adsorption characteristics of zn (ii) from dilute aqueous solution by fly ash. Colloids and Surfaces A: Physicochemical and Engineering Aspects 2004, 247, 137-143.

163. Mohan, S.; Gandhimathi, R. Removal of heavy metal ions from municipal solid waste leachate using coal fly ash as an adsorbent. Journal of Hazardous Materials 2009, 169, 351-359.

164. Salam, O.E.A.; Reiad, N.A.; ElShafei, M.M. A study of the removal characteristics of heavy metals from wastewater by low-cost adsorbents. Journal of Advanced Research 2011, 2, 297-303.

165. Nascimento, M.; Soares, P.S.M.; Souza, V.P.d. Adsorption of heavy metal cations using coal fly ash modified by hydrothermal method. Fuel 2009, 88, 1714-1719.

166. Papandreou, A.; Stournaras, C.; Panias, D.; Paspaliaris, I. Adsorption of pb (ii), zn (ii) and cr (iii) on coal fly ash porous pellets. Minerals Engineering 2011, 24, 1495-1501.

167. Kuncoro, E.P.; Fahmi, M.Z. Removal of hg and pb in aqueous solution using coal fly ash adsorbent. Procedia Earth and Planetary Science 2013, 6, 377-382. 